\title{
40. SEDIMENTOLOGY AND ORIGIN OF LOWER CRETACEOUS PELAGIC CARBONATES AND REDEPOSITED CLASTICS, BLAKE-BAHAMA FORMATION, DEEP SEA DRILLING PROJECT SITE 534, WESTERN EQUATORIAL ATLANTIC ${ }^{1}$
}

\author{
A. H. F. Robertson, Department of Geology, University of Edinburgh, West Mains Road, Edinburgh EH9 3JW \\ United Kingdom \\ and \\ D. M. Bliefnick, Gulf Research and Development Company, P.O. Box 36506, Houston, Texas
}

\begin{abstract}
Drilling at Site 534 in the Blake-Bahama Basin recovered $268 \mathrm{~m}$ of Lower Cretaceous, Berriasian to Hauterivian, pelagic carbonates, together with volumetrically minor intercalations of claystone, black shales, and terrigenous and calcareous clastics. Radiolarian nannofossil pelagic carbonates accumulated in water depths of about 3300 to $3650 \mathrm{~m}$, below the ACD (aragonite compensation depth) but close to the CCD (calcite compensation depth). Radiolarian abundance points to a relatively fertile ocean. In the Hauterivian and Barremian, during times of warm, humid climate and rising sea level, turbiditic influxes of both terrigenous and calcareous sediments, and minor debris flows were derived from the adjacent Blake Plateau. The claystones and black shales accumulated on the continental rise, then were redeposited onto the abyssal plain by turbidity currents. Dark organic-rich and pale organic-poor couplets are attributed to climatic variations on land, which controlled the input of terrigenous organic matter. Highly persistent, fine, parallel lamination in the pelagic chalks is explained by repeated algal "blooms." During early diagenesis, organic-poor carbonates remained oxygenated and were cemented early, whereas organic-rich intervals, devoid of burrowing organisms, continued to compact later in diagenesis. Interstitial dissolved-oxygen levels fluctuated repeatedly, but bottom waters were never static nor anoxic. The central western Atlantic in the Lower Cretaceous was thus a relatively fertile and wellmixed ocean basin.
\end{abstract}

\section{INTRODUCTION}

IPOD Leg 76 drilled $392 \mathrm{~m}$ (with a recovery of $268 \mathrm{~m}$ ) of Berriasian to Hauterivian, mostly calcareous, pelagic sediments and minor clastics in the Blake-Bahama $\mathrm{Ba}-$ sin. A distinctive succession, termed the Blake-Bahama Formation by Jansa et al. (1979), exists widely over the western central Atlantic (Fig. 1); similar sediments are also present in the eastern Atlantic (Lancelot, Seibold, et al., 1978; Jansa et al, 1978) and in the western Tethys, as the Maiolica facies (Bernoulli, 1972; Bernoulli and Jenkyns, 1974; Robertson and Bernoulli, 1981). The succession at Site 534 closely resembles that at Site 391, about $20 \mathrm{~km}$ to the southwest (Benson, Sheridan, et al., 1978; Freeman and Enos, 1978). Together, the two sites closely document Early Cretaceous paleoenvironments in the western equatorial Atlantic Basin. In this chapter we describe and interpret the lithofacies in an attempt to clarify the paleoenvironment of this part of the Atlantic. Current hypotheses do not take into full account depositional mechanisms as revealed by details of sedimentary structures and petrography. For example, here we show that much of the Early Cretaceous black shale has been redeposited by turbidity currents from within the oxygen-minimum zone on the continental rise; thus it is not necessary to postulate an Early Cretaceous "oceanic-anoxic event."

${ }^{1}$ Sheridan, R. E., Gradstein, F. M., et al., Init. Repts. DSDP, 76: Washington (U.S. Govt. Printing Office).

\section{Lithological Units and Age Data}

The base of the Blake-Bahama Formation is placed close to the Tithonian/Berriasian boundary (Sheridan, Gradstein et al., this volume), where predominantly reddish gray calcareous claystones and biomicritic marly limestones pass up into very light gray, bioturbated, nannofossil chalks rich in radiolarians (Core 92, Fig. 2). At Site 391, the Blake-Bahama Formation is divided into four subunits, 4a to 4d (Freeman and Enos, 1978). The same formation at Site 534 is also divided into four subunits (5a-5d), based on the relative abundance of lithologic types, and can be correlated with the type section at Site 391. Subunit 5d, dated as early Berriasian to late Berriasian, consists of burrowed radiolarian-rich nannofossil limestones with subordinate clay partings. Nannofossils indicate that the base of the Blake-Bahama Formation falls at the base of Core 91 (Site 534 report, this volume). Subunit $5 c$, mostly early Valanginian, consists of similar nannofossil limestones but with an increasing abundance upward of marly nannofossil chalks, claystones, and siltstones. Subunit $5 \mathrm{~b}$, dated as early and late Valanginian, comprises radiolarian-rich nannofossil chalk, with subordinate siltstones, claystones, and nannofossil limestones. Lastly, Subunit 5a (Fig. 2), extending from late Valanginian, through Hauterivian to Barremian, contains abundant intercalations of sandy and silty limestones and calcareous siltstones, claystones, and marly nannofossily chalks. The boundary with the overlying Upper Cretaceous Hatteras Formation is gradational and is taken to be where the sedi- 


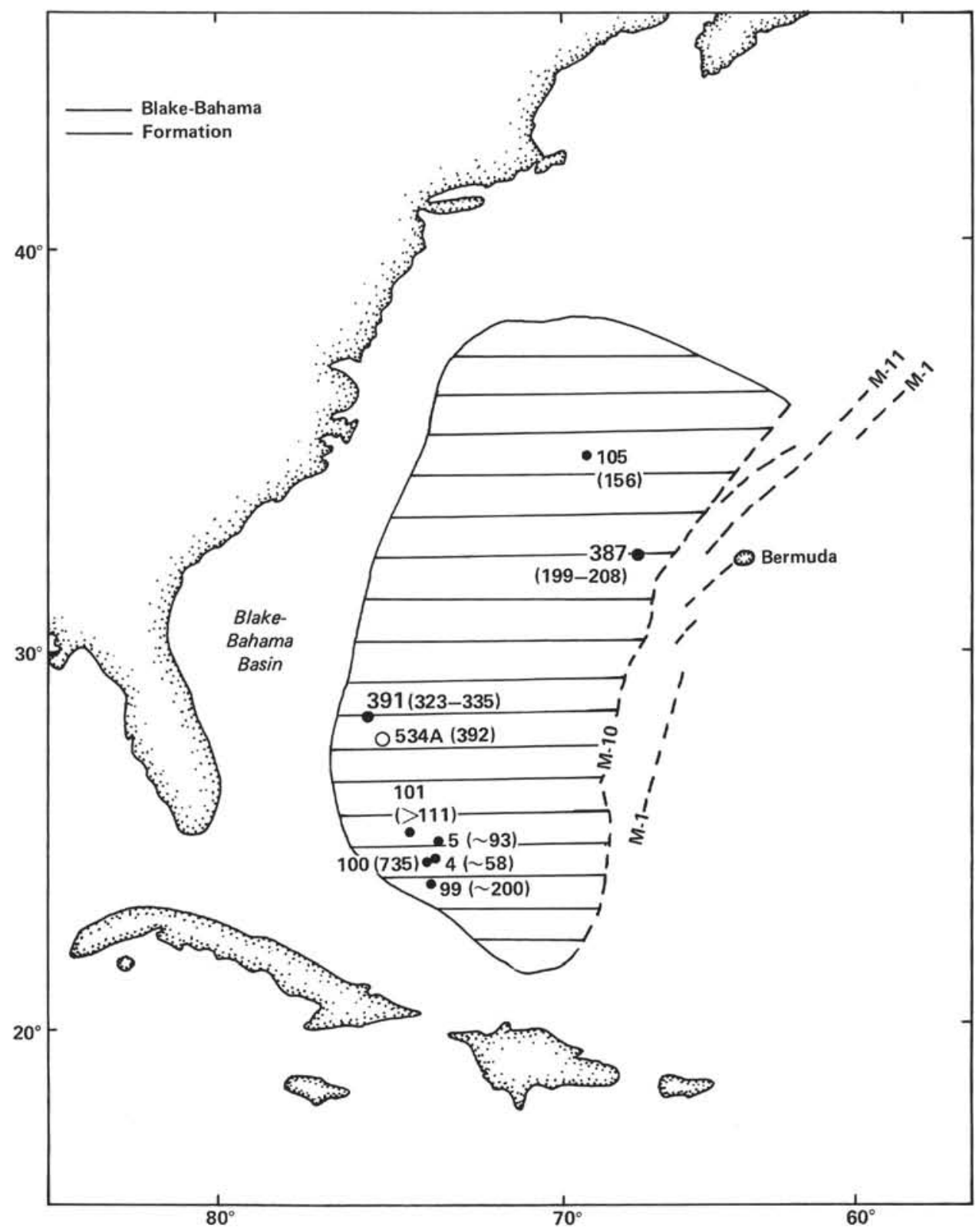

Figure 1. Map showing areas where Early Cretaceous pelagic limestones have been drilled in the western central Atlantic. (Thickness in meters of the Blake-Bahama Formation is shown in parentheses. Horizon $\beta$ correlates approximately with the top of the Blake-Bahama limestones; the eastern boundary indicates pinch-out against basement, near Magnetic Anomaly M-11, interpreted as Valanginian [modified after Jansa et al., 1978].)

ments become much less calcareous (Core 47), indicating deposition close to the calcite compensation depth. The succession then passes into dark, gray black, calcareous claystones, nannofossil claystones, and sandy and silty limestones with minor black carbonaceous claystones, dated as Albian-Aptian (Site 534 report, this volume).

\section{LITHOLOGIES}

Rock names follow those employed by DSDP (see Explanatory Notes, this volume). Four main lithologies are recognized: (1) nannofossil limestone, (2) marly nannofossil chalks, (3) claystones, and (4) redeposited clastics. For terrigenous sediments, the suffix "stone" is added where the rock is too hard to cut with a wire. Chalk is defined as hard, firm, partly indurated calcareous ooze, or friable limestone readily scratched with a fingernail or the edge of a spatula blade. Limestones are defined as hard, cemented, or recrystallized calcareous rocks. Thus the chalks and limestones described here in some cases differ only in hardness. Marly is used to denote transitional terrigenous-biogenic sediments $(<10 \%$, siliceous microfossils; $<30 \%$, terrigenous components, $>30 \% \mathrm{CaCO}_{3}$ ). At Site 534 , the claystones are of two types, the first greenish, the other dark gray to black and carbonaceous (black shale). The redeposited clastics 


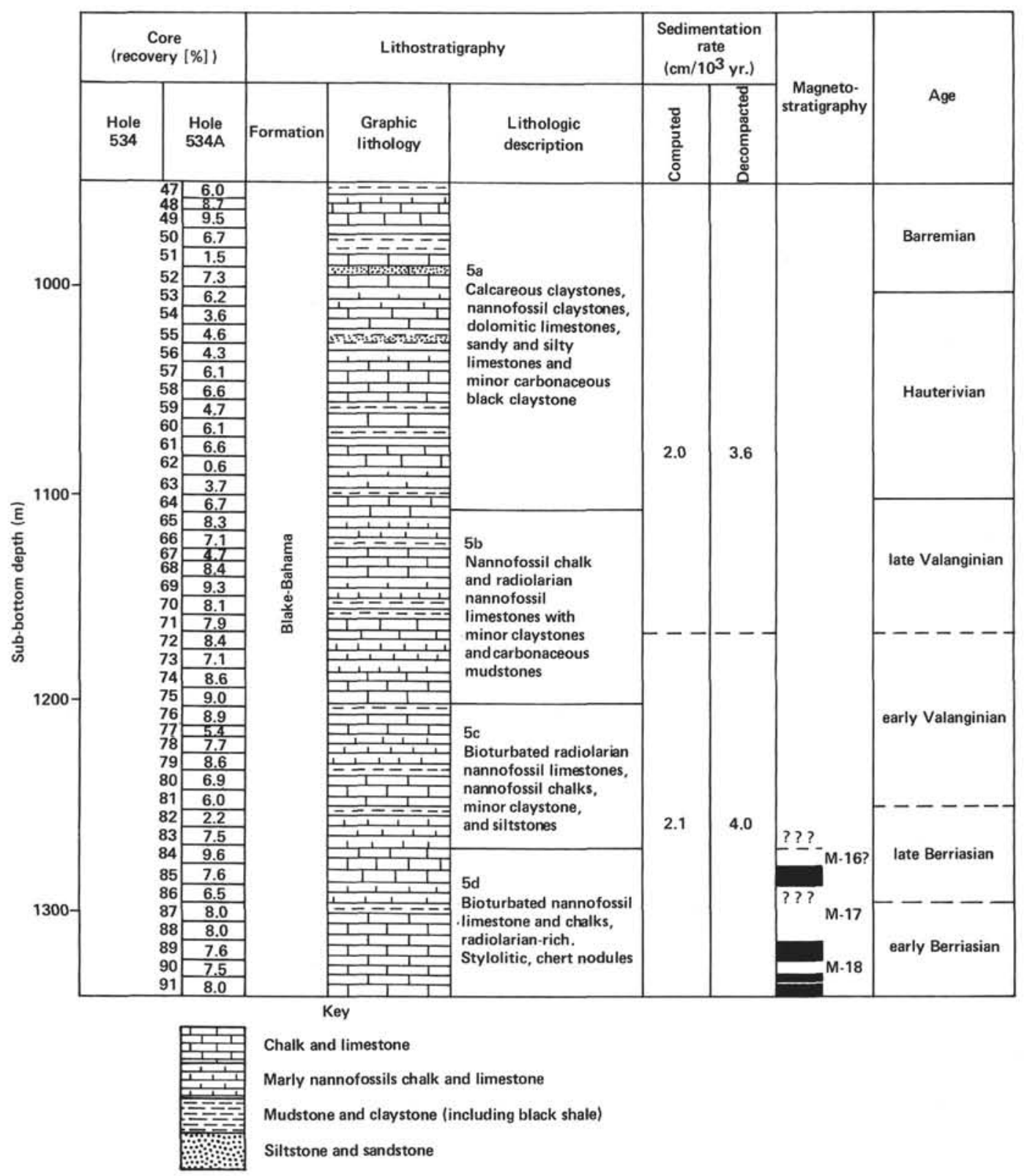

Figure 2. Summary of subdivisions of the Blake-Bahama Formation into 4 subunits. (Paleontological age assignments and lithologic summary are shown. See the Site 534 report for details of formations above [Hatteras] and below [Cat Gap].)

may be divided into quartzose siltstones, fine sandstones, and more abundant sandy limestones.

The relative abundance of the various lithofacies is shown in Fig. 3. The early Berriasian was dominated by nannofossil limestones, which became less abundant upward and disappeared by the end of the late Valanginian. During the Valanginian, nannofossil limestones gave way progressively to less well-lithified nannofossil chalks. The late Berriasian to late Valanginian nannofossil chalks were divided on the ship into darker and lighter laminated subfacies. Redeposited clastics are restricted to the late Valanginian to Barremian; they became dominant in the early Hauterivian. Claystones occur throughout the succession but reached a relative maximum in the late Valanginian. The black carbona- ceous shales are present above the lower Berriasian, locally reaching $25 \%$ of the lithologies in a single core (Fig. 3). Several of the lithologies are common to more than one of the four subunits. To avoid repetition, the following description is by lithology, rather than rock assemblage, which is the basis of the division into subunits given in the Site 534 report (this volume).

\section{Nannofossil Limestones}

\section{Macroscopic Features}

The lower-upper Berriasian, which forms much of Subunit $5 \mathrm{~d}$, is dominated by very light gray, fine-grained limestones that are moderately to highly burrowed (Fig. $4 \mathrm{~A}$ and B, Fig. 5B). There are two color variants: very 


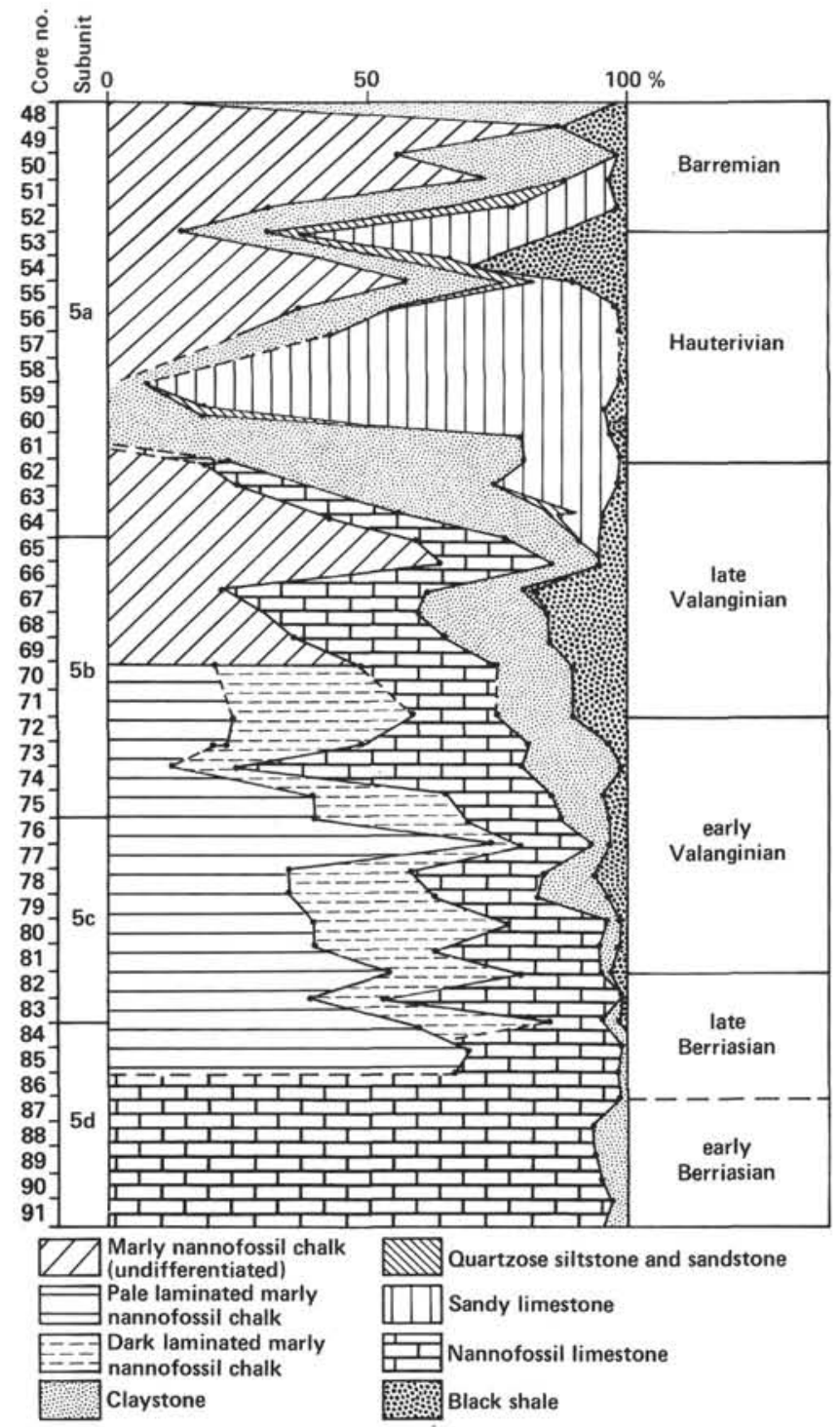

Figure 3. Summary of relative abundance of lithologies of the BlakeBahama Formation drilled in Hole 534A. (The quartzose siltstones and fine-grained sandstones and sandy limestones were deposited by turbidity currents. Note the relative abundance of dark organicrich claystones [black shales]. Marly nannofossil chalks, in both burrowed and laminated forms, give way to nannofossil limestones in the early Berriasian. The diagram was compiled from Site 534 report data.)

light gray to bluish white; and light bluish gray. Both color variations can be seen in single cores (e.g., Core 86, Berriasian). Exceptionally, Section 5 of Core 83 (late Berriasian) from $30 \mathrm{~cm}$ downward is composed of strongly burrowed limestones with a reddish tinge, reminiscent of the underlying Tithonian and Kimmeridgian Cat Gap Formation (Sheridan, Gradstein, et al.; Ogg et al., this volume). In general, the darker nannofossil limestones are more argillaceous, often with tiny claystone stringers. We also found several thin intraformational breccias (with subangular limestone clasts up to $2 \mathrm{~cm}$ in diameter) in a slightly darker matrix of similar micritic limestone (e.g., Core 89, Section 1, $133 \mathrm{~cm}$; and Section 3, $64 \mathrm{~cm}$ ). Lamination is occasionally offset by minute normal faults, with throws up to $2 \mathrm{~cm}$ (Fig. 4B). Small vertical burrows are conspicuous in the early Berriasian (Cores 89-90), but Chondrites-type burrows are more numerous throughout (Fig. 4A).

Diagenetic features, described in more detail in a later section, include scattered nodules of chalcedonic quartz chert (e.g., Core 88, Section 5, 85-88 cm). Stylolites are present, particularly in the purer limestones (e.g., Fig. 4A). Some limestones show an incipient nodular texture composed of diagenetic carbonate segregations up to several centimeters in diameter.

The nannofossil limestones become progressively less abundant in the late Berriasian to early Valanginian, giving way to marly nannofossil chalks, which occur extensively in Subunits 5a to 5c.

\section{Petrography}

The nannofossil limestones show relatively little petrographical variation (Figs. 8A, B; Table 1). Most are composed of calcite-replaced or pyritized radiolarians in a micritic matrix, typically showing incipient recrystallization to microspar. Other grains include pellets, skeletal fragments, and phosphatic grains. Thin interbeds of massive dark green clay are common. There are also occasional small geopetals (e.g., Core 80, Section 2, 79-81 $\mathrm{cm})$. The lower part of radiolarian molds is occasionally micrite-filled, whereas the upper part contains finegrained sparry calcite. Radiolarians are mostly orientated parallel to bedding, indicating at least some current action, as well as compaction. Texturally, the interval of red micritic limestones, seen in Core 83 , is identical to the intercalated gray limestones. In rare cases (e.g., Core 88 , Section $5,88-90 \mathrm{~cm}$ ) the radiolarian micrite is incipiently chertified. Radiolarian shells there are filled with either translucent brown or gray chalcedonic quartz, as seen in plane-polarized light. The sediment is normally so churned by bioturbation that neither burrows nor sedimentary structures can be identified. The sediment is now virtually homogenous.

The scanning-electron microscope (SEM) shows mostly poorly preserved coccoliths overgrown with sparry calcite. Former radiolarian shells are usually filled with sparry calcite or else exist as cavities with smooth interiors; the shell exteriors are overgrown with prismatic spar crystals.

\section{Marly Nannofossil Chalks}

\section{Macroscopic Features}

From the upper Berriasian (above Core 85) to the lower Valanginian, the nannofossil limestones give way progressively to softer marly nannofossil chalks (Figs. $6 \mathrm{~A}, \mathrm{~B} ; 7 \mathrm{~A}, \mathrm{~B})$. All the nannofossil chalks described are clay-rich to some extent (see the analyses that follow). The transition is marked by a change from mottled light colored limestone with green clay intraclasts to darker gray chalks and black clay interbeds.

Much of the upper Berriasian to lower Valanginian (Subunit 5c) interval is made up of alternations of two 


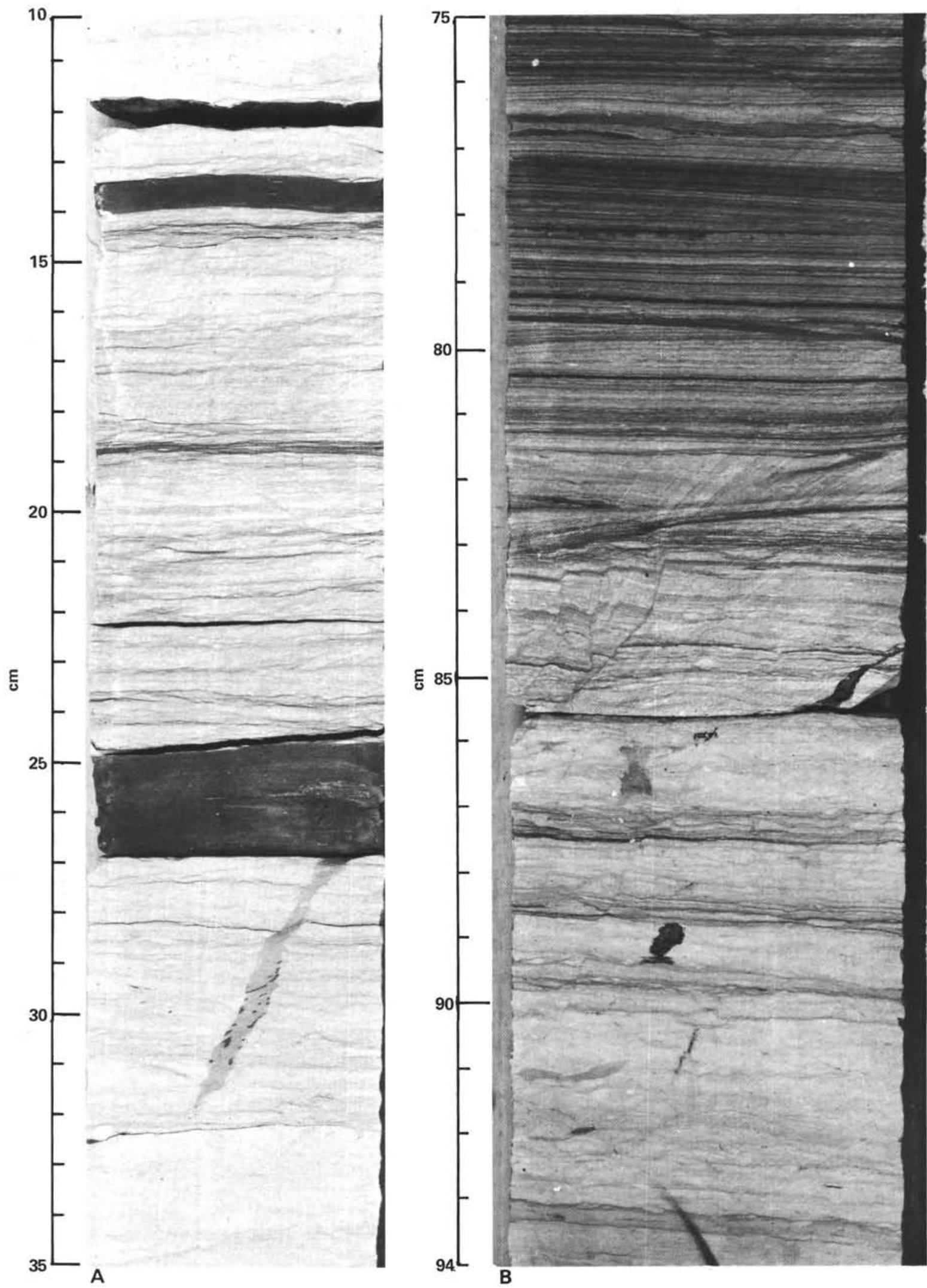

Figure 4. Nannofossil limestone facies. A. Typical nannofossil limestone and interbedded dark claystones of the Berriasian inter$\mathrm{val}$. (Note the intense small-scale burrowing, occasional large burrows, and the tendency for darker, more organic-rich laminae to be nonburrowed-Core 90 , Section $1,10-35 \mathrm{~cm}$.) B. Nannofossil limestone transitional to laminated marly nannofossil chalk. (Note the small-scale burrowing breaking down fine lamination, also the small normal faults that are not believed to be a drilling artifact-Core 85 , Section $1,75-94 \mathrm{~cm}$.) 

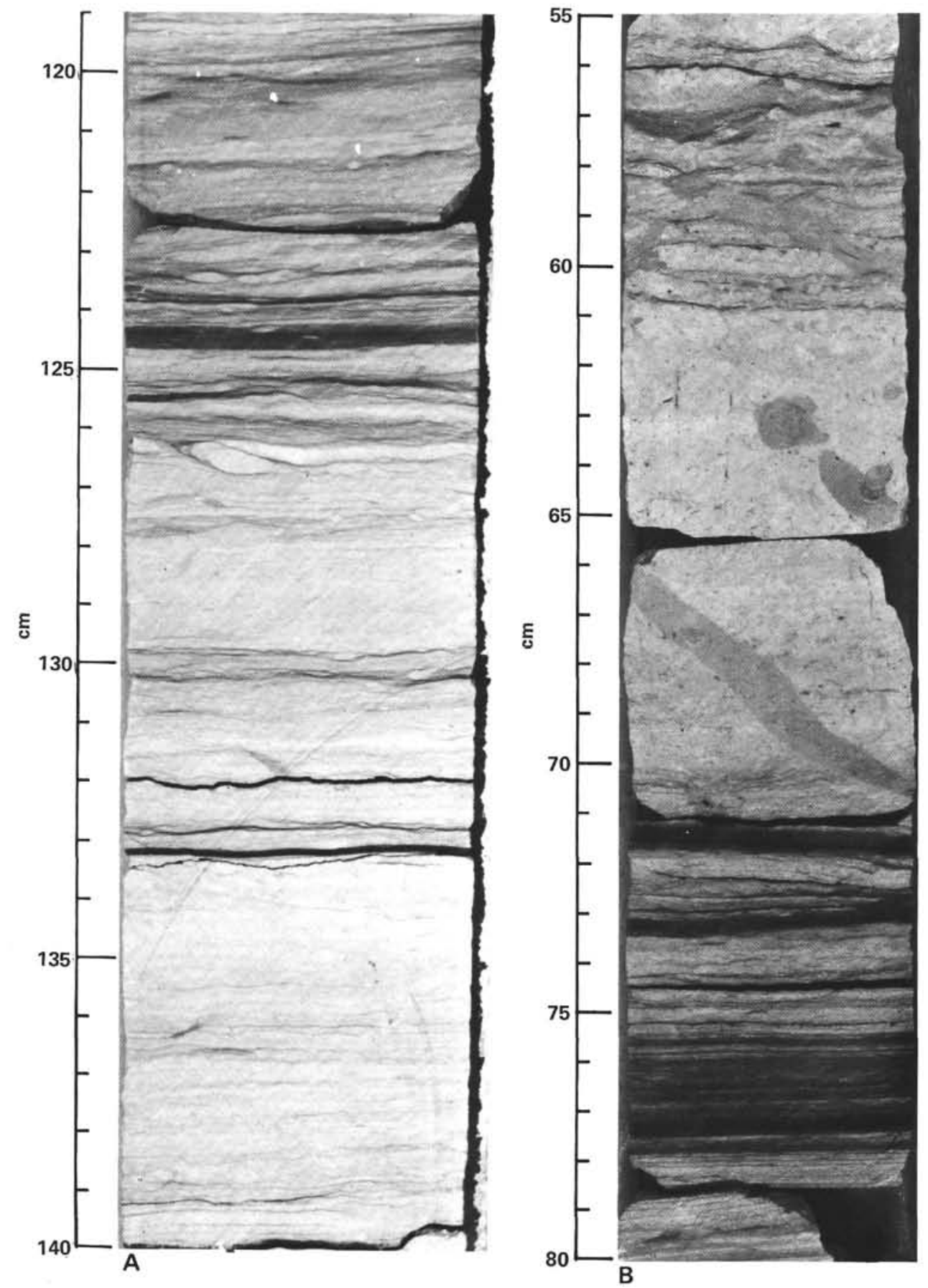

Figure 5. Core photographs of limestones. A. Typical appearance of the extensively bioturbated nannofossil limestone. (Whispy laminae are dark hemipelagic siliceous mudstones, partially mixed with the limestone by burrowing organisms. Compaction has resulted in formation of very small-amplitude stylolites in the mudstone [132 and $133 \mathrm{~cm}$ ]. Diagenetic cementation has resulted in an incipient micronodular texture in which clay laminae are relatively abundant [121-131 cm]-Sample 534A-87-5, 119$140 \mathrm{~cm}$.) B. Nannofossil limestone typical of the lower part of the Blake-Bahama Formation (Berriasian-early Valanginian). (Note the intense burrowing on both small and large scales $[60-70 \mathrm{~cm}]$, the small scale stylolites $[55-60 \mathrm{~cm}]$, and that the lower claystone laminae are not burrowed-Sample $534 \mathrm{~A}-72-6,55-80 \mathrm{~cm})$.

sublithologies: (1) burrowed marly nannofossil chalks; (2) finely laminated unburrowed nannofossil chalks.

\section{Burrowed Marly Nannofossil Chalks}

The marly nannofossil chalks texturally closely resemble the nannofossil limestones. Intense burrowing obscures the original sedimentary lamination, which may be still just recognizable (Fig. 7B). The most burrowed nannofossil chalks tend to be the most cemented, transitional to the nannofossil limestones just described, and may be stylolitized. Colors are normally light gray, light olive gray, and medium dark gray. In general, the dark- 
Table 1. Summary of point-count data for selected Hole 534A samples of Blake-Bahama Formation rocks viewed with the optical microscope.

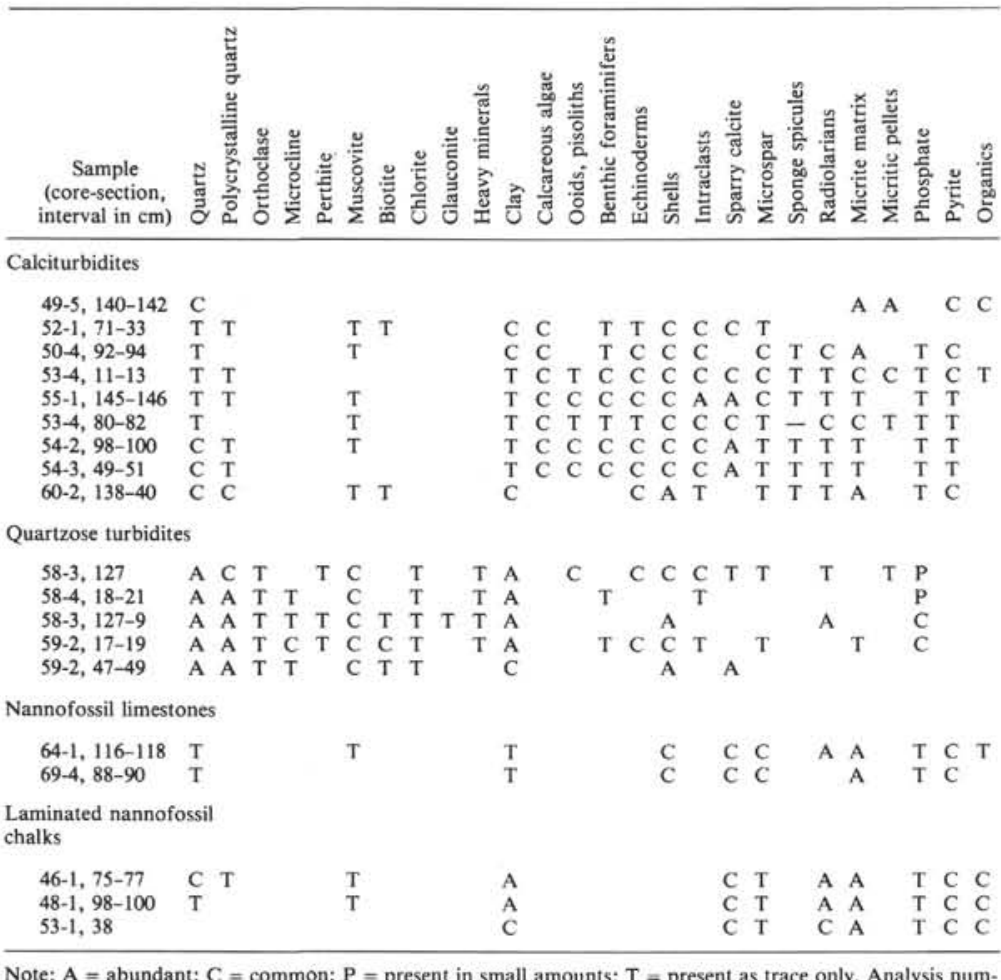

bundant; $\mathrm{C}=$ common; $\mathrm{P}=$ present in small amounts; $\mathrm{T}=$ present as trace only. Analysis num

ber $=20$.

er burrowed nannofossil chalks tend to show the most conspicuous burrowing (e.g., Core 83). The burrow-fill material is often slightly coarser than the host sediment. Rare aptychi, shell fragments, and scattered "calcispheres" are visible in some sections.

\section{Laminated Marly Nannofossil Chalks}

In contrast, the other lithology is invariably finely and regularly laminated with little or no burrowing (Fig. 7A). From the lower Valanginian upward (from Core 78 , Subunits $5 \mathrm{~b}, \mathrm{c}$ ), the laminated marly nannofossil chalks are themselves divisible into two "end-member" lithologies: (1) pale laminated marly nannofossil chalks; (2) dark laminated marly nannofossil chalks (Fig. 6B). In the first category, colors range from light gray to light olive gray, with numerous white and occasionally dark particles $1 \mathrm{~mm}$ in diameter. The second lithologic category is similar but darker, with colors ranging from medium and greenish gray to greenish black. The two laminated nannofossil chalk lithologies are smoothly intergradational on various scales, typically several tens of centimeters. The relative proportions of light and dark laminated and bioturbated chalks change markedly from core to core, and one does not consistently dominate over the other.

As examples of the detailed variations seen in Core 77 (lower Valanginian, Subunit 5 b), both the paler laminated and the darker marly nannofossil chalk lithologies are present in significant amounts (Fig. 7B). In Core 74, the darker type is there but still subordinate. By contrast, in Core 72 the darker lithology is more common, and even the paler laminated chalks contain thin black carbonaceous laminae up to several millimeters thick. Alternations of the two laminated lithologies are seen in the overlying upper Valanginian interval (e.g., Cores 69, $68,67,66,65,64$, Subunit 5 b). In contrast, Core 63 is dominated by gray laminated marly nannofossil chalks, and in Core 61 only the paler lithology is present. In the Hauterivian (Subunit 5a), the laminated nannofossil chalks are diluted by increased clastic intercalations (see the following discussion on Cores 50-55).

The Barremian interval of the Blake-Bahama Formation (Cores 52-46 inclusive, Subunit 5a) is dominated by marly nannofossil chalks, with subordinate claystones, burrowed chalks, and terrigenous clastics. Of these, Cores 50 and 49 consist mostly of the pale laminated marly nannofossil chalk sublithology, whereas pale and dark varieties are present in subequal abundance in Cores 48 and 47 . The two lithologies are again smoothly intergradational (e.g., Core 47). Several intervals of the paler gray sublithology grade into burrowed limestones, but the darker sublithology is invariably nonburrowed (e.g., Core 48, Section 1, 6-148 cm), and becomes more abundant in the transition to the Hatteras Formation (Figs. 8A, B).

\section{Petrography}

Both the laminated (Fig. 8E, F) and bioturbated (Fig. $8 \mathrm{C}$ ) chalks are composed of micrite and contain scattered quartz, calcified radiolarians, streaks and blebs of organic matter, phosphatic grains, and calcite debris, which may be recrystallized fossil fragments (Figs. 8A- 

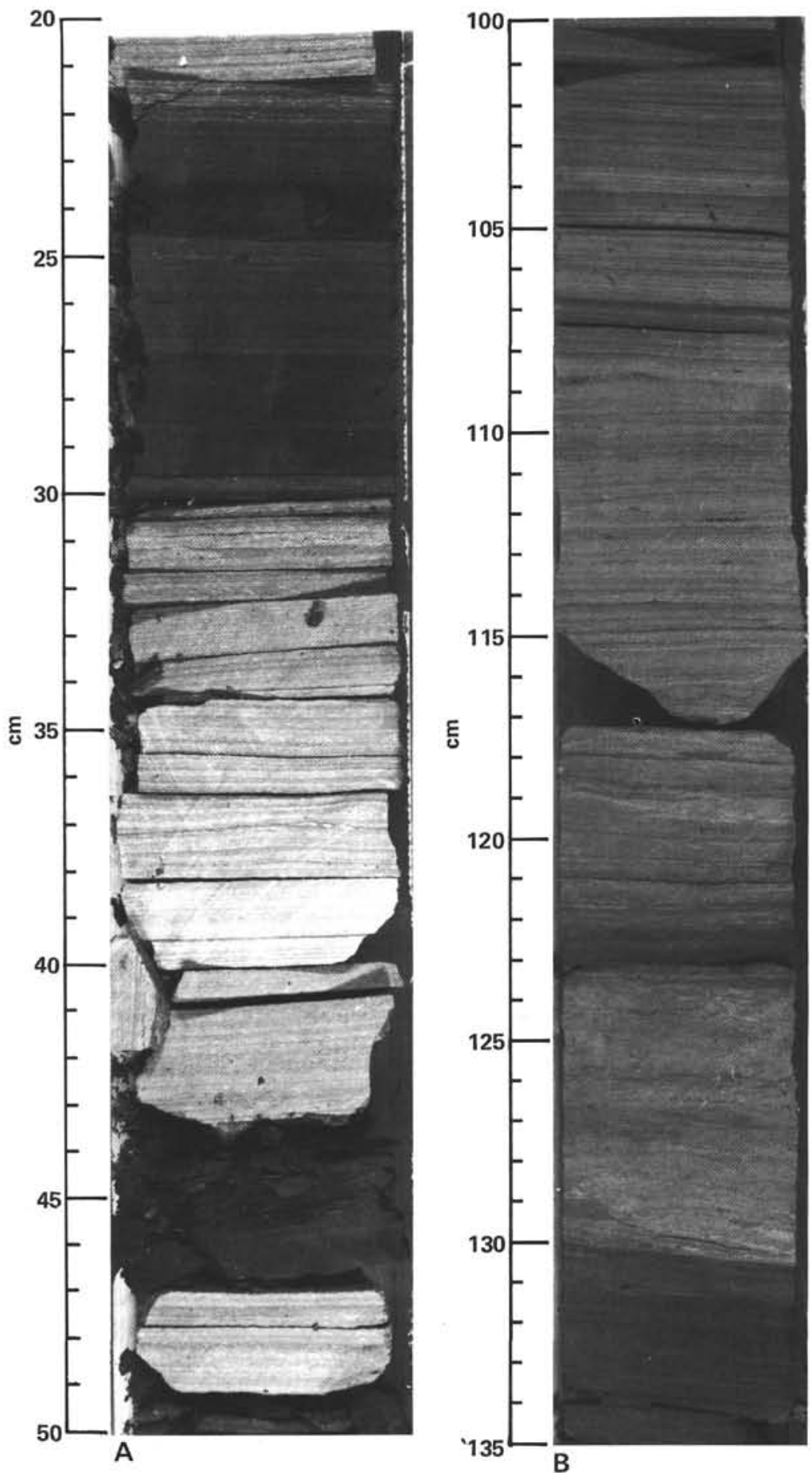

Figure 6. Core photographs of marly nannofossil chalk. A. The interval from 30 to $40 \mathrm{~cm}$ is typical of the paler sublithology of the marly nannofossil chalks in Core 64 , Section 4, 20-50 cm. (Note the continuous, but slightly irregular laminations and the white elongate specks that are calcified radiolarians. The interval from 20 to $30 \mathrm{~cm}$ comprises the darker sublithology-laminated, unburrowed nannofossil chalks-intercalated with several $\mathrm{cm}$ of thick graded claystones). B. This sample $(534 \mathrm{~A}-49-4,100-135 \mathrm{~cm})$ is dominated by the paler subfacies of the marly nannofossil chalks showing disappearance of lamination due to burrowing.

C, Table 1). Textures are mudstones and wackestones; elongate grains are orientated horizontally (Fig. 8C). Some marly chalks contain eroded and abraded clasts of previously cemented marly chalk. These features indicate at least minor involvement of current activity in the deposition of the marly chalk. By Core 74 (lower Valanginian, Subunit $5 \mathrm{~b}$ ), not only are the radiolarians orientated horizontally, but many of them are flattened, possibly due to compaction during diagenesis. In this interval some radiolarians are also partially to completely 

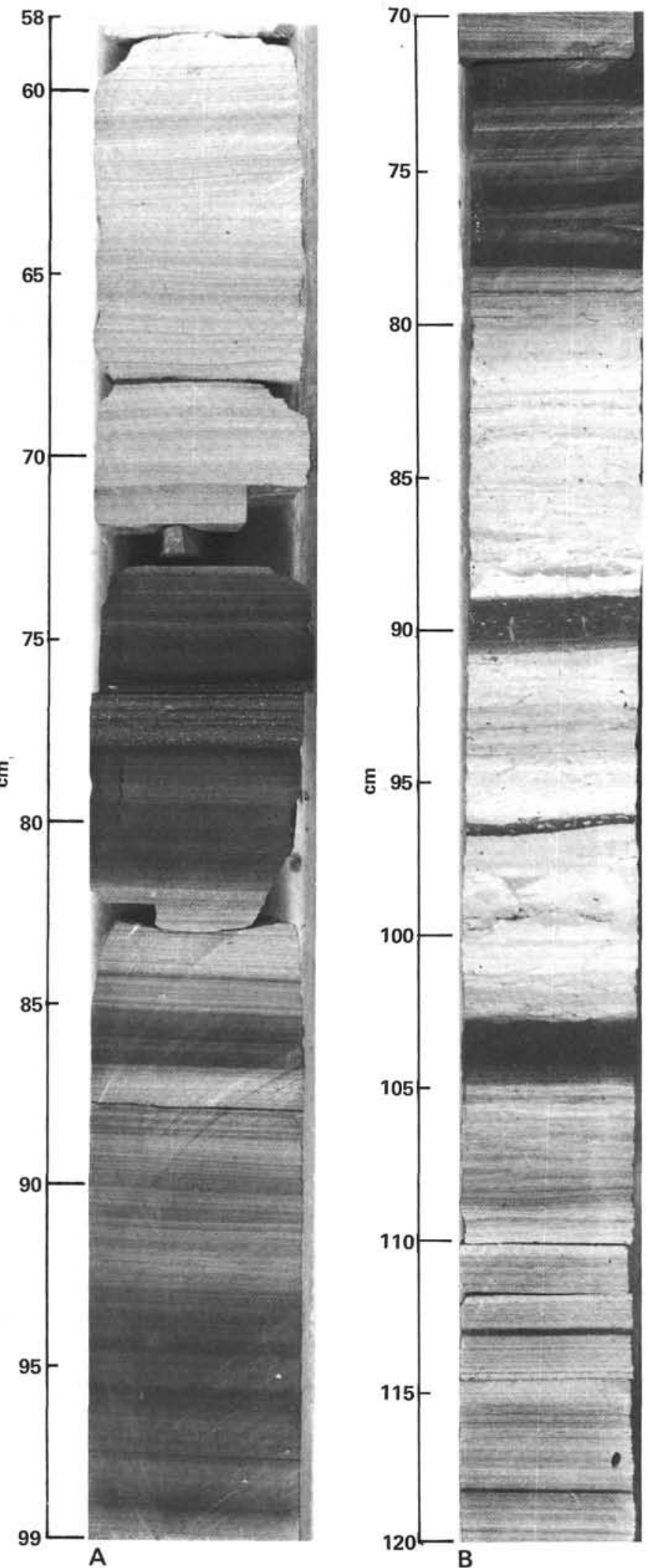

Figure 7. Core photographs of marly nannofossil chalk facies showing alternating darker and lighter colored marly nannofossil chalk. The subfacies in A. is the medium gray material $(58-72 \mathrm{~cm})$, whereas the darker, more carbonaceous intervals are typical of subfacies in B. A. Note the complete lack of burrowing, and the even regular plane lamination, apart from slightly irregular lamination from 60-70 $\mathrm{cm}$. (Also note white specks [from 76-78 cm]-these are calcified radiolarians [Core 48, Section 1 , $58-99 \mathrm{~cm}]$.) B. This sequence is dominated by the pale laminated nannofossil chalks but also includes dark mudstones and light colored, bioturbated limestones (Core 75, Section 3, 70-120 cm). 


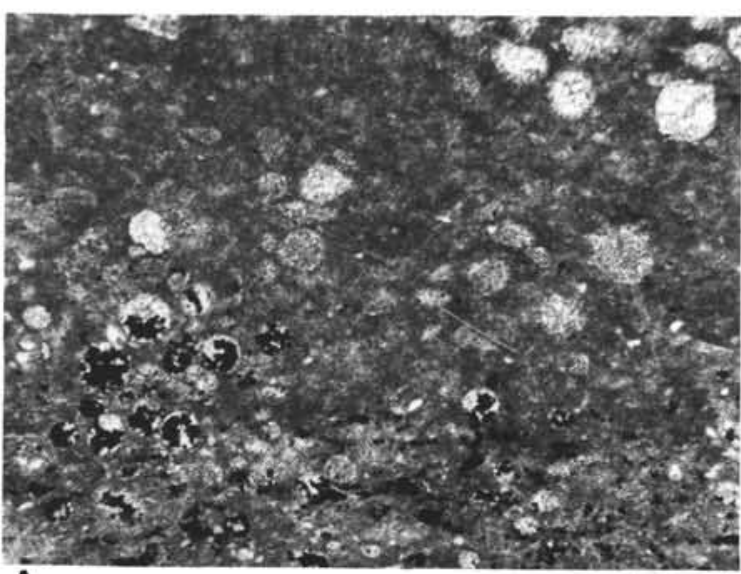

A

$1 \mathrm{~mm}$

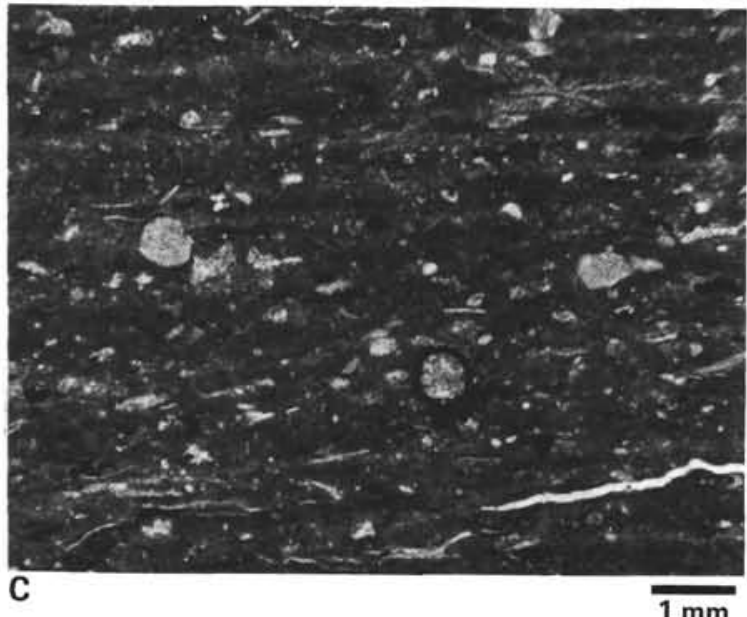

$1 \mathrm{~mm}$

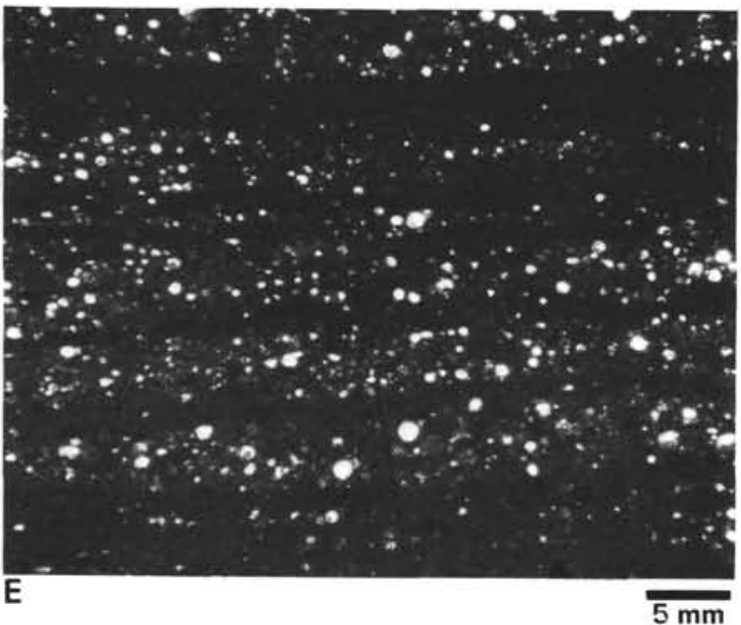

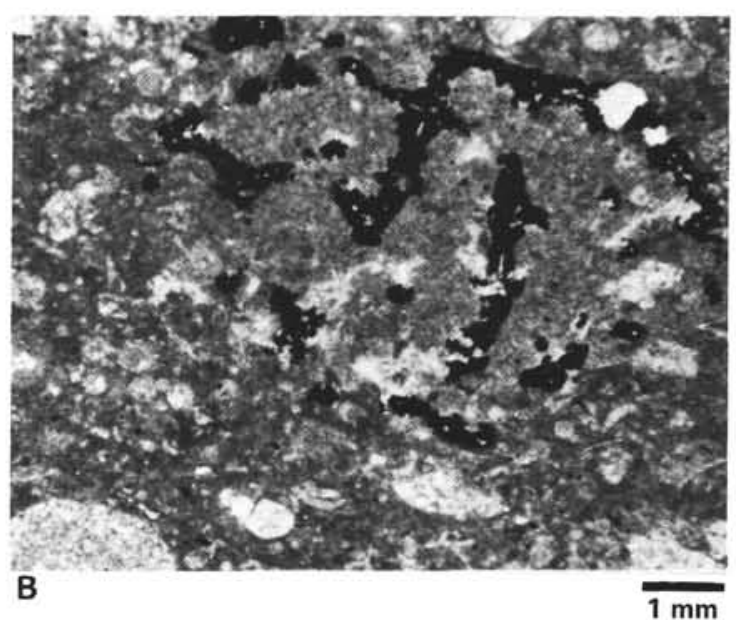
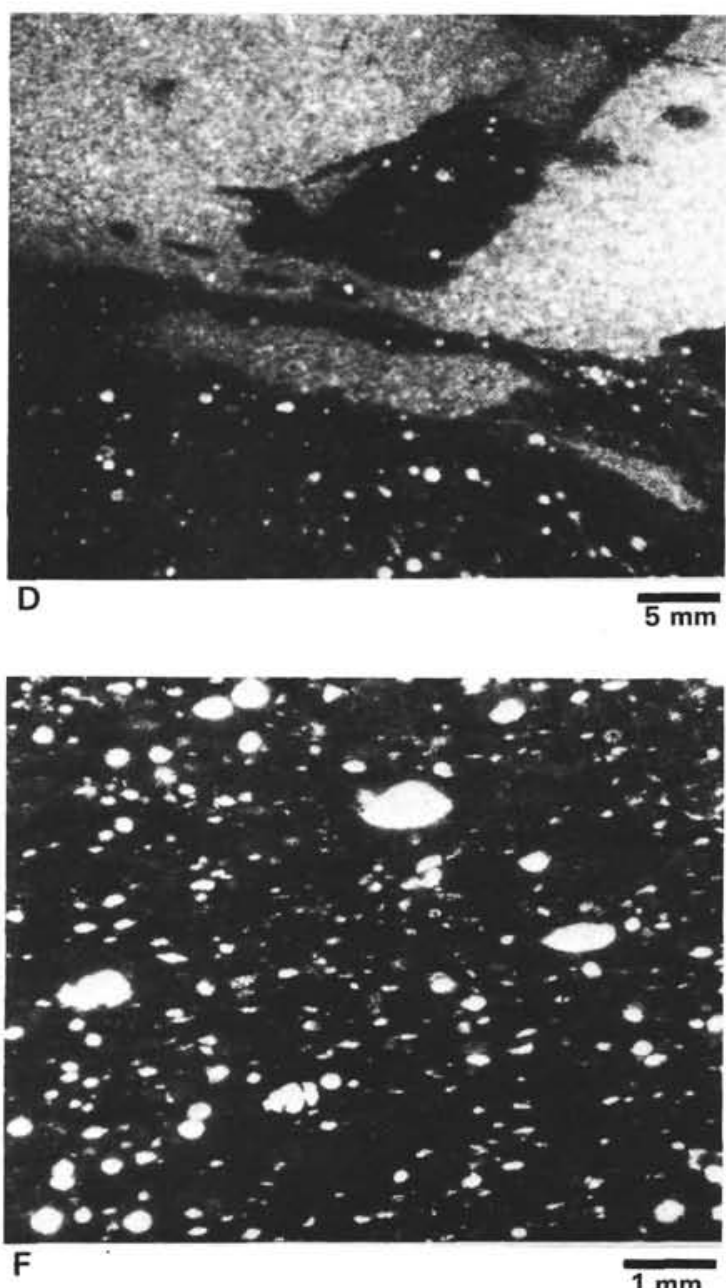

$1 \mathrm{~mm}$

Figure 8. Photomicrographs of marly nannofossil oozes and limestones under plane-polarized light. A. Nannofossil limestone. (Note the radiolarians, not flattened, but replaced by calcite in a micritic to microspar matrix. Many of the tests are partly replaced by pyrite-Sample 534A-79-2, 74-76 cm.) B. Marly nannofossil limestone. (More pyritized remnants of meshwork of large radiolarian. Larger radiolarians, which are pyritized, are preserved without deformation, but smaller tests, which are replaced by calcite, show more evidence of flattening-Sample 534A-52-1, 69-71 cm.) C. Marly nannofossil chalk. (Shells of spherical radiolarians are pyritized and infilled with calcite spar. Matrix is marly micrite. Unlike Fig. $8 \tilde{\mathrm{A}}$ or $\mathrm{B}$, this sample $(534 \mathrm{~A}-56-3,38-40 \mathrm{~cm}$ ) is mixed with terrigenous quartzose silt.) D. Bioturbated marly nannofossil chalk showing the contrast between massive micrite and the marly nannofossil chalk adjacent, which contains numerous calcite-replaced radiolarians. (In this instance-Sample 534A-55-1, 13-15 cm-the burrows are clearly visible but this is often not the case. E. Laminated chalk containing abundant calcitized radiolarians. (The radiolarians are for the most part spherical, and the slight horizontal orientation may be due to compaction-Sample $534 \mathrm{~A}-48-3,50-52 \mathrm{~cm}$.) F. Laminated marly chalk. (The radiolarians have been infilled with calcite spar, flattened, and some have been pyritized-Sample $534 \mathrm{~A}-68-5,55-58 \mathrm{~cm}$. 
pyritized (Fig. 8A, B). With increasing depth and increasing cementation, many of the chalks would have become limestones, as described earlier.

The fine lamination in the nannofossil chalks is hard to resolve at high magnification (Fig. 8E). Laminae are accentuated by lines of horizontally orientated and flattened replaced radiolarians (calcispheres). Micrite adjacent to these replaced shells tends to be preferentially recrystallized to microspar. Laminae may also be accentuated by tiny elongate thin-walled shell fragments that have not been identified and are too thin to be Posidonia "filaments." In darker nannofossil marls, laminations often comprise numerous elongate carbonaceous flecks and minor phosphate, in a micritic matrix. The paler laminations tend to be a more homogeneous micrite than the darker ones, which are often more argillaceous.

The fine lamination can sometimes be resolved into tiny en echelon streaks at highest magnifications. The streaks comprise pure micrite and have fused to give the appearance of a regular parallel lamination (e.g., Core 80 , Section 5 , at $47 \mathrm{~cm}$, lower Valanginian) Well-defined parallel laminae in the paler nannofossil chalk sublithology comprises micrite that is slightly more recrystallized and better cemented than the interlaminar chalk. Darker laminations are often accompanied by minute clay wisps, tiny micritic concretions $(0.01 \mathrm{~mm}$ in diameter $)$, and microscopic stylolites.

Individual fine lamination can sometimes be resolved in scanning electron micrographs of broken rock surfaces (Fig. 9A). The matrix is made up of almost featureless micritic limestone, with occasional poorly preserved coccoliths welded together and overgrown by sparry calcite (Fig. 9B). Partial recrystallization to "blocky" spar is common (Fig. 10B, C). Plant material is visible in the darker laminations. Where diagenesis is less advanced in the chalks, coccoliths, discoasters, and other skeletal fragments are easily identified (Fig. 9C, D, Fig. 10A-D).

\section{Claystones}

\section{Macroscopic Features}

The calcareous claystones exist as two distinct lithologies, which are shown in Figure 3. These are greenish gray claystone and darker, more carbonaceous claystone. The main features of the two types are described next.

Near the Formation base in the Berriasian (Subunit $5 \mathrm{~d})$, the calcareous claystones are restricted to up to 3.5$\mathrm{cm}$-thick (but normally thinner) intercalations, which range from massive to laminated, with both plane and wavy laminations (Figs. 4A, 5A). Colors range from dark greenish gray, to greenish black, olive gray and brownish gray. Intercalations are often weakly size-graded (e.g., Core 90). The claystones exist as thin, anastomosing stringers, often showing wavy lamination (e.g., Fig. 4A).

In the upper Berriasian, above Core 87 (Subunit 5d), claystones are often 1 to $3 \mathrm{~cm}$ thick, showing grading and parallel lamination. In addition, there are numerous partings several millimeters thick (e.g., Core 87,
Section 2, 100-125 cm), which could not be shown accurately on the barrel sheets (Sheridan, Gradstein et al., Site 534 report, this volume), but are recorded on the visual description forms (Site 534 report, this volume). Normally, the fine carbonaceous laminae are parallel, but these laminations are exceptions anastomosing complexly (Core 86, Section 2, 75-106 cm).

In the lower Valanginian (Subunits $5 \mathrm{~b}, \mathrm{c}$ ) above Core 80 , the darker carbonaceous claystones become relatively more abundant (Fig. 3). Some relevant details concerning these and other claystone types follow.

In Core 79, the claystones are restricted to seven thin, graded, partings in Sections 1 and 2; Sections 3 through 6 consist entirely of nannofossil limestone. In Core 78 two distinct claystone types are visible, the first dark gray to greenish-black, the other dark greenish gray to greenish black; both types are massive, graded, and up to $5 \mathrm{~cm}$ thick. By Core 77, the darker, more organic-rich claystones are slightly thicker and more abundant than their more greenish counterparts. In Core 76,38 welldefined claystone intervals were counted in the six sections, plus numerous more minor partings. Bases of the well-defined claystones show ripple lamination, as well as plane lamination and grading. Both the darker and lighter intervals in Core $\mathbf{7 4}$ have rare Chondrites and other small burrows in the upper part of graded beds. From Core 72 the darker claystones are clearly more carbonaceous, black or dark gray, and can be classified as "black shales." In Core 76 the black claystones are associated with small pyrite nodules.

From Core 64 onward (upper Valanginian), the claystones are intercalated with redeposited clastic facies (see the following discussion). Locally, in Cores 60 to 62 (Fig. 11A), claystones become the dominant lithology (Valanginian/Hauterivian boundary). Intercalations up to $0.5 \mathrm{~m}$ thick (e.g., Core 61, Section 3, 4-56 cm) are themselves composed of repeated graded partings, $3 \mathrm{~cm}$ thick, on the average. Only the basal 0.5 to $1 \mathrm{~cm}$ is graded, whereas small Chondrites burrows are restricted to the tops of beds. Occasionally, cross lamination is visible. After Core 59 (Hauterivian, Subunit 5a), claystones are again highly subordinate (e.g., Fig. 11B). Cores 60 to 51 show typical, thin-graded intercalations of grayblack carbonaceous claystones, as seen lower in the succession (Fig. 11A, B). After Core 51 in the Barremian (Subunit 5a) to the top of the Blake-Bahama Formation, there is a return to thicker, more massive claystone intercalations, as also seen at the Formation base in the transition to the Tithonian Cat Gap Formation. For example, individual intercalations, which show little signs of gradings, are up to $20 \mathrm{~cm}$ thick in Core 51 , and $33 \mathrm{~cm}$ thick in Core 50 (Section 2, 20-53 cm). These dark claystones are laminated throughout with burrowed and more massive layers containing pyrite.

\section{Petrography}

In thin section, the claystones have a constant composition, with scattered calcite-replaced or pyritized radiolarians. Recrystallization of the matrix is not seen in thin section. The basal several-centimeter-thick graded intervals contain numerous calcified or pyritized radio- 

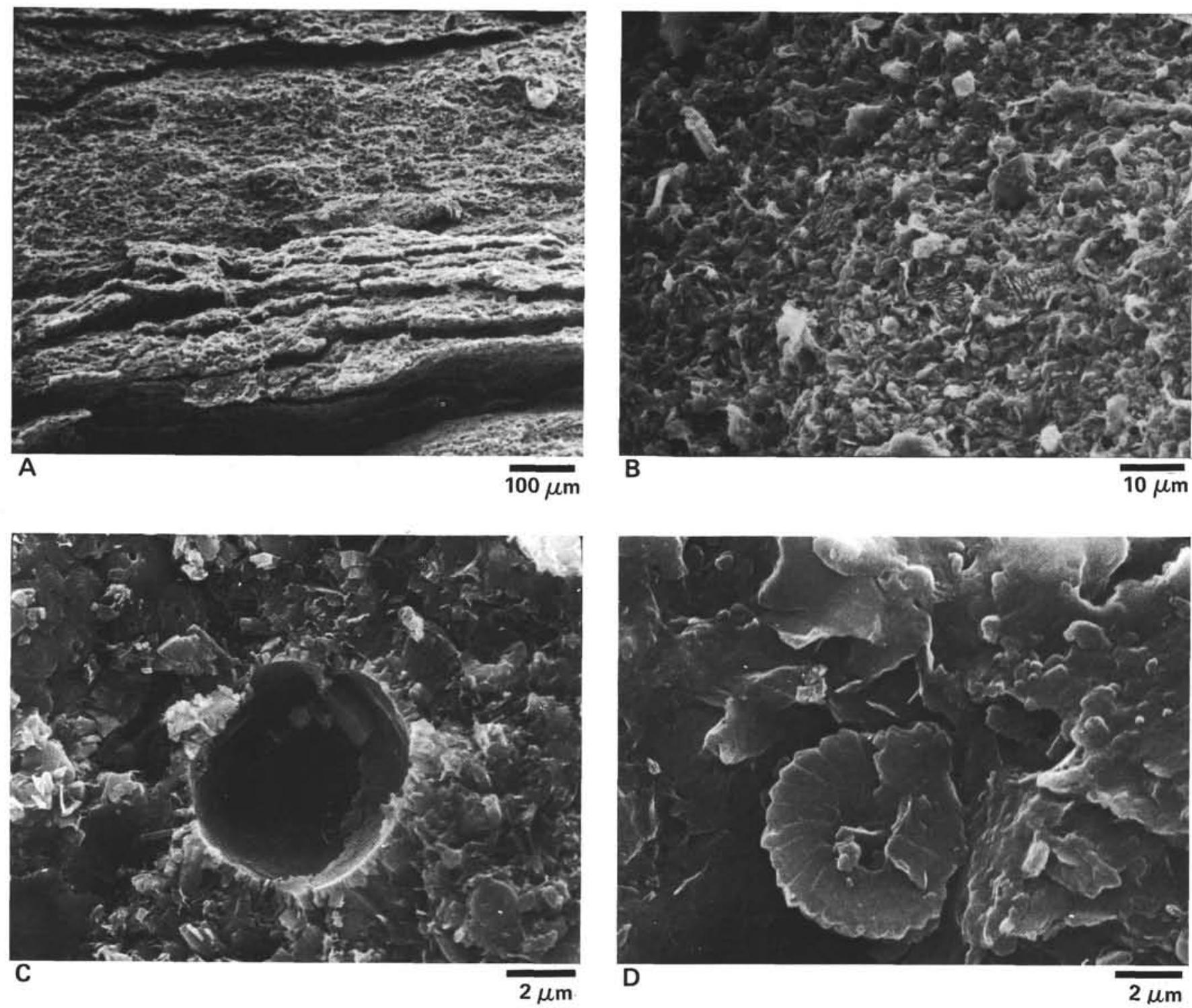

Figure 9. Scanning electron micrographs of marly nannofossil chalk. A. Here the thin and anastomosing laminae are composed of clay and are characteristic of the lower part of the formation (Core 83, Section 5, 115-117 cm). B. Scanning electron micrograph of nannofossil chalk. (The nannofossil material may become so disaggregated as to be unidentifiable and is merely called microcrystalline carbonate-Core 61 , Section 1 , $8-12 \mathrm{~cm}$.) C. Dissolved radiolarian shell (Core 71 , Section $4,80-82 \mathrm{~cm}$ ). D. Partly dissolved coccoliths, partly overgrown with sparry calcite (Core 71 , Section $4,80-82 \mathrm{~cm}$ ).

larians, rare benthic foraminifers (Moullade, this volume), minute shell fragments, fish-debris, and scattered, relatively well-rounded quartz grains. Many of the radiolarians are mud-filled rather than recrystallized to calcite. Where the claystones become most abundant in the upper Valanginian/Hauterivian (Cores 60-62), they contain fine-grained, quartzose silt. The black carbonaceous claystones contain, in addition, large amounts of opaque organic matter (see Habib, this volume), pyritized radiolarians, and phosphatic matter, including fish teeth.

With the scanning electron microscope, the claystones are seen to differ from the nannofossil chalks (Figs. 12, 13). The claystone texture is open and porous, with abundant calcareous nannoplankton, which are often moderately to well preserved (Fig. 12A-D). In one sam- ple (534A-48-2, 165-167 cm), the coccoliths show slight to moderate calcite overgrowths (Fig. 13A, B). Occasional complete coccospheres are present (Fig. 12C). A sample from Core 47 , Section $2(84-86 \mathrm{~cm})$ is porous but shows extensive calcite overgrowths. (Fig. 13C, D). Plant material is occasionally visible (Fig. 12D).

\section{Redeposited Clastics}

\section{Macroscopic Features}

Distinctive clastic intervals first appear in the lower Valanginian, around Core 65 (base of Subunit 5b) (Fig. 3 ), then become coarser and thicker-bedded upward, reaching a maximum in the upper Hauterivian to lower Barremian. The relevant features of these clastic beds, which define Subunit 5a, are discussed next. 

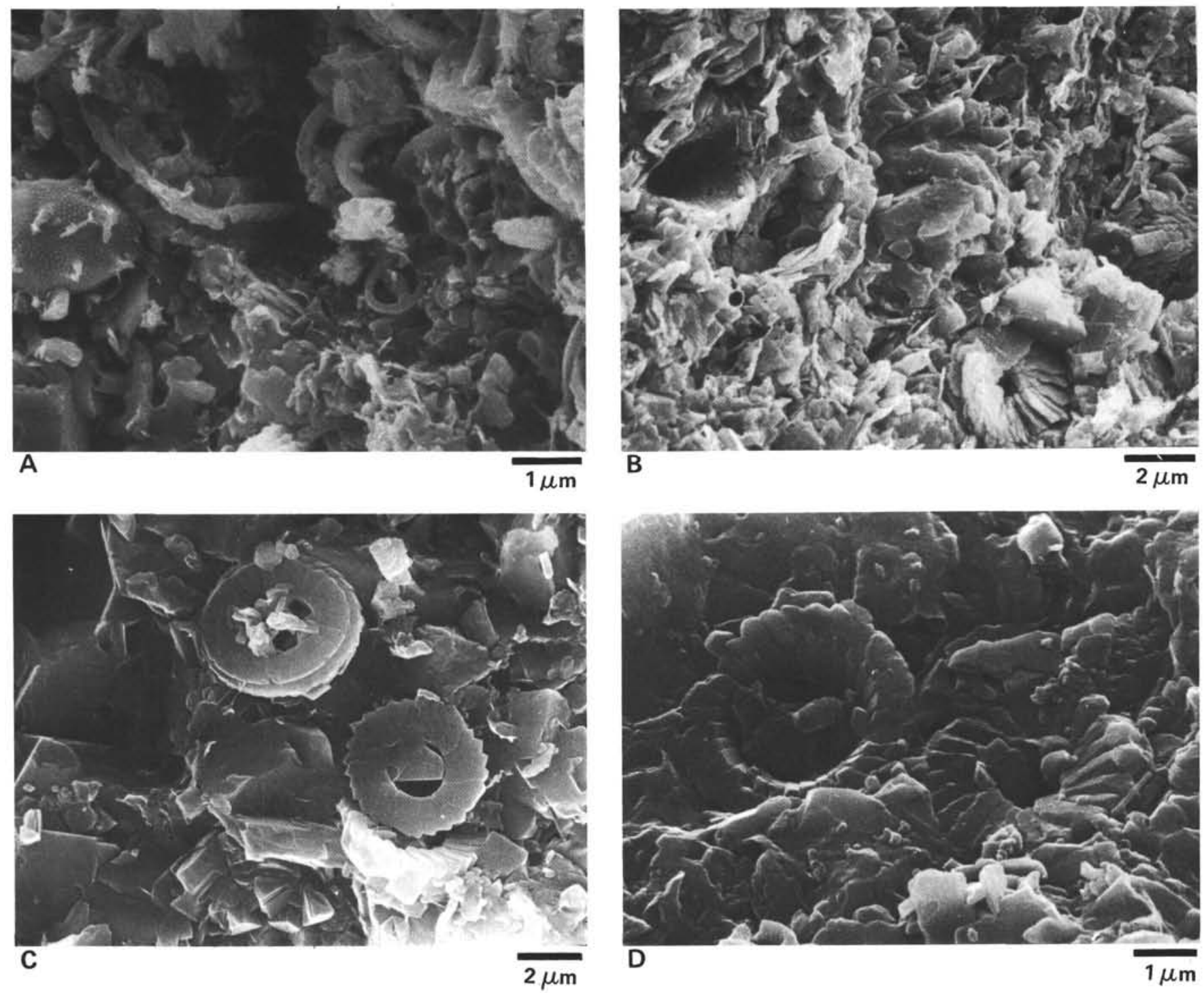

Figure i0. Scanning electron micrographs of marly nannofossil chalks. A. Nannofossil debris consisting of coccoliths, discoasters, diatoms, and less frequently, pieces of radiolarians and sponge spicules forms the bulk of both the laminated and burrowed chalks; little diagenesis has occurred in this sample (534A-48-3, 50-52 cm). B. This sample is similar to Fig. 10A except that it has undergone more disaggregation and possibly a little more cementation; note dissolved shell in upper left (Sample 534A-66-4, 93-98 cm). C, D. Core 71, Section 3, 80-82 cm-coccoliths heavily overgrown with blocky calcite crystals showing more advanced diagenesis.

At first significant appearance, around Core 75 , the clastics are restricted to graded siltstone partings, less than $2.5 \mathrm{~cm}$ thick. By Core 63 , the clastics are medium gray calcareous siltstones up to $3 \mathrm{~cm}$ thick, showing parallel and cross lamination. In Core 62 the clastics are composed of medium dark gray cross-laminated sandy limestones, as intercalations up to $25 \mathrm{~cm}$ thick. Hand specimens are conspicuously micaceous. The sandy limestones possess sharp bases and often sharp tops overlain by claystone.

After Core 60 (Subunit 5a), low in the Hauterivian, both terrigenous and carbonate clastic horizons become thicker and more numerous (Fig. 3). Some beds are partly recrystallized to limestones, others exist as well-lithified calcareous siltstone, often moderately to strongly burrowed. Bases of beds tend to be preferentially calcite-cemented. In this interval, individual beds range up to $30 \mathrm{~cm}$, but are mostly 5 to $15 \mathrm{~cm}$ thick. Individual bases of beds are occasionally load-casted (e.g., Core 60 , Section $4,78-80 \mathrm{~cm}$ ).

From Core 59 upward, convolute lamination is seen in addition to grading, plane, and ripple lamination (e.g., Core 59, Section 2, 94-96 cm). The clastic material reaches a maximum in Core 58 (Hauterivian), with numerous intercalations of quartz-mica-feldspar-rich limestones, up to $40 \mathrm{~cm}$ thick (Fig. 14A, B). One of these clearly shows the T b, c, d Bouma turbidite intervals, with particularly well developed convolute lamination $(15-30 \mathrm{~cm}$, Section 1), and another shows the chaotic arrangements of angular, poorly sorted grains with a matrix-supported fabric characteristic of debris flows. Upper levels of the calciturbidites are typically moderate to strongly burrowed, occasionally with small stylolites in strongly calcite-cemented parts of beds (e.g., Core 58, 

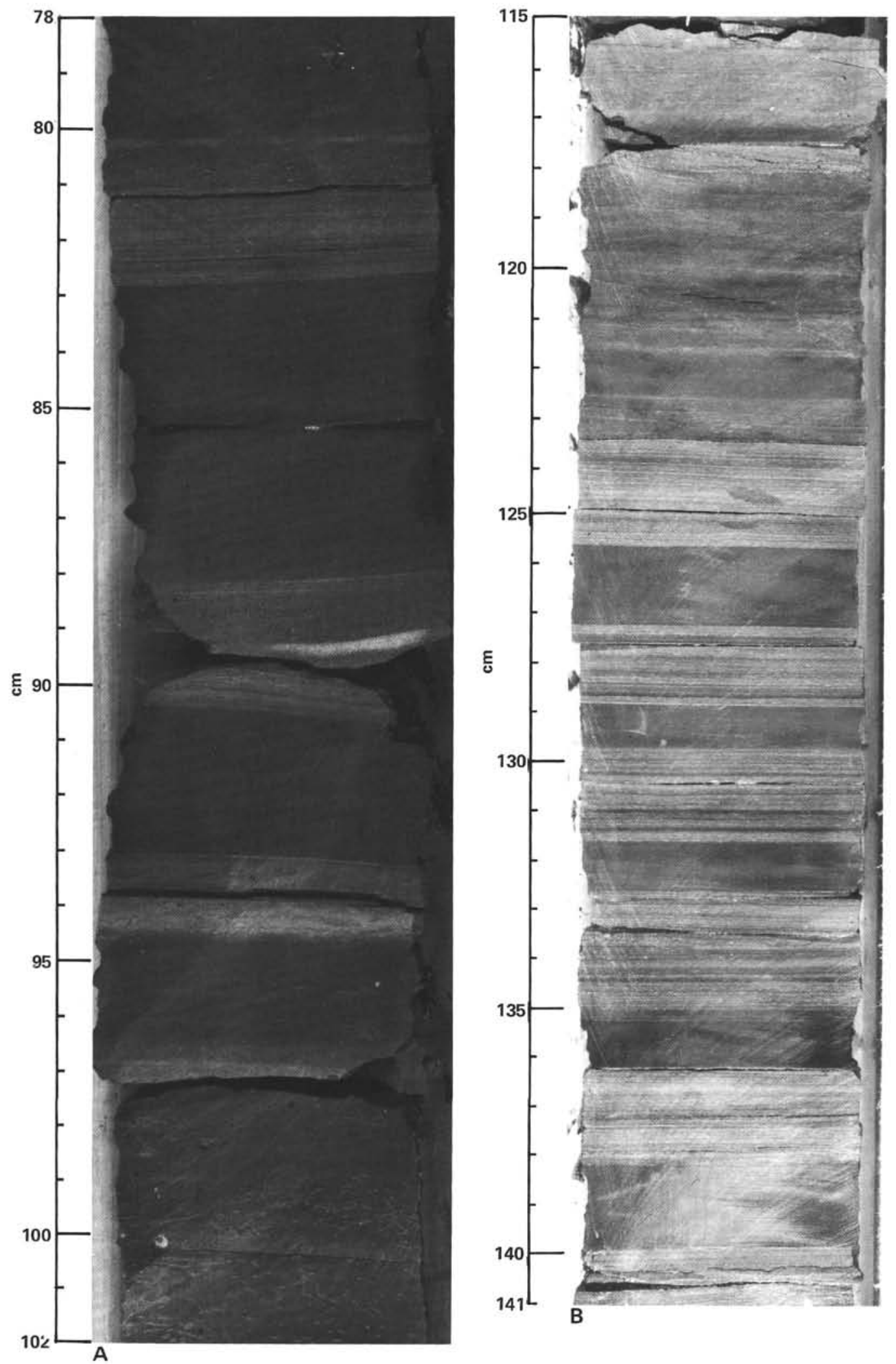

Figure 11. Claystone facies. A. Turbiditic calcareous claystone (Sample 534A-60-1, 78-102 cm). (Note the grading over about $1 \mathrm{~cm}$ [e.g., $80-81 \mathrm{~cm}$ ] and small-scale ripples [rare]. Most of the claystones are massive and unburrowed, whereas the lowest claystone $[98-102 \mathrm{~cm}]$ is moderately burrowed. Note also the intercalated finely laminated marly nannofossil chalks [sublithology 1].) B. Thin-bedded, turbiditic claystones intercalated with finely laminated marly nannofossil chalk (Sample 534A-58-1, 115-141 cm). (Slight grading over the basal few millimeters is visible with a hand lens. Note the sharp bases but either the sharp or the gradational tops of the claystone turbidites.) 

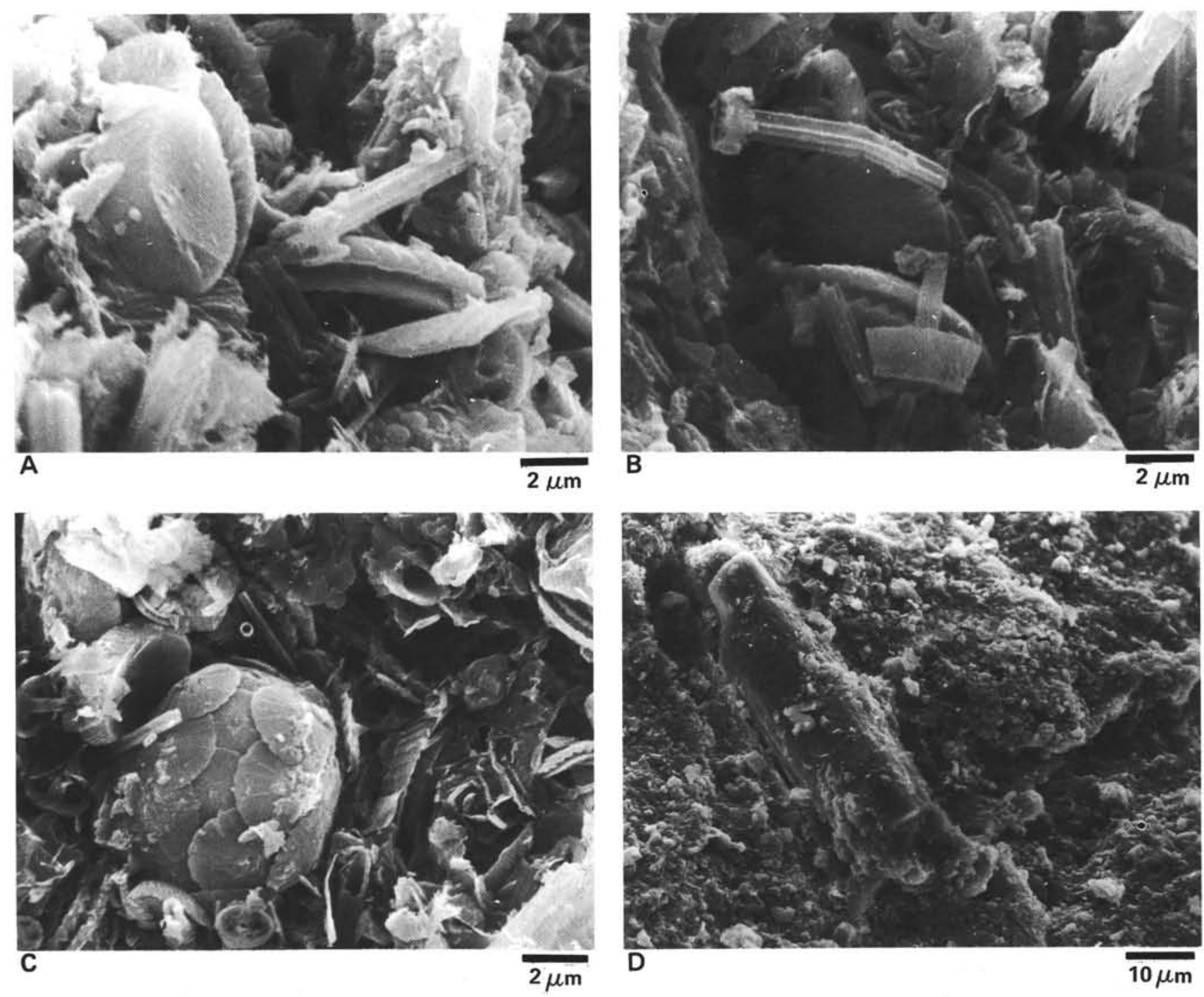

Figure 12. Scanning electron micrographs of claystone turbidites and marly nannofossil chalks (Sample $534 \mathrm{~A}-48-2,165-167 \mathrm{~cm}$ ). A, B. Nannofossil chalks (note excellent preservation of coccoliths with relatively little cementation and calcite overgrowths). C. Well-preserved calcareous nannofossil plankton. D. Fragment of plant material.

Section 4, 114-124 cm). In several cases the bases of beds are pyritized (e.g., Core 58, Section 4, $80-90 \mathrm{~cm}$ ). The top of individual turbidites is often missing, possibly due to postdepositional erosion.

The thickest- and coarsest-grained clastic beds (seen in Core 58, Sections 1-5) (Hauterivian, Subunit 5a) include scattered shell fragments and black organic pellets. In this core, the distinctive interval from 30 to $110 \mathrm{~cm}$ is a single sedimentation unit: 103 to $110 \mathrm{~cm}$ is massive packstone with clay intraclasts; 97 to $103 \mathrm{~cm}$ is almost massive packstone; 45 to $53 \mathrm{~cm}$ is composed of very highly convoluted fine- to medium-grained packstone, with intraclasts of silt-sized carbonate up to $5 \mathrm{~cm}$ long and internal convolute lamination (also in this interval are some clasts of massive gray claystone and black shale); 40 to $45 \mathrm{~cm}$ is fine packstone with gray calcareous claystone intraclasts up to $1 \mathrm{~cm}$ long; 30 to 40 $\mathrm{cm}$ is finer-grained, massive, mottled, and moderately burrowed calcareous claystone with parallel laminations at the base.
Above Core 57 the redeposited clastics decrease in grain size, bed thickness, and abundance; grading, parallel and cross lamination dominate, without convolutelaminated intervals. From Core 55 (Hauterivian, Fig. 16B) upward, the thin, fine-grained, clastic horizons resemble those below Core 60 (late Valanginian, Fig. 15B). A good example of grading is seen in Core 55, Section 3 , from $90-105 \mathrm{~cm}$. Several partings contain scattered plant fragments orientated parallel to bedding. Above Core 54 (Fig. 15B), in the Barremian, the redeposited clastics mostly show only grading and parallel lamination, without ripples (Td, e). Then after Core 49 (Barremian), the clastics virtually disappear.

\section{Petrography}

Individual redeposited clastic horizons vary greatly in the abundance and composition of redeposited shallowwater carbonate and terrigenous clastic material (Fig. 16, Table 1). Most intervals (e.g., Core 60, Section 3, $20-22 \mathrm{~cm}$ ) are strongly dominated by quartz with subor- 

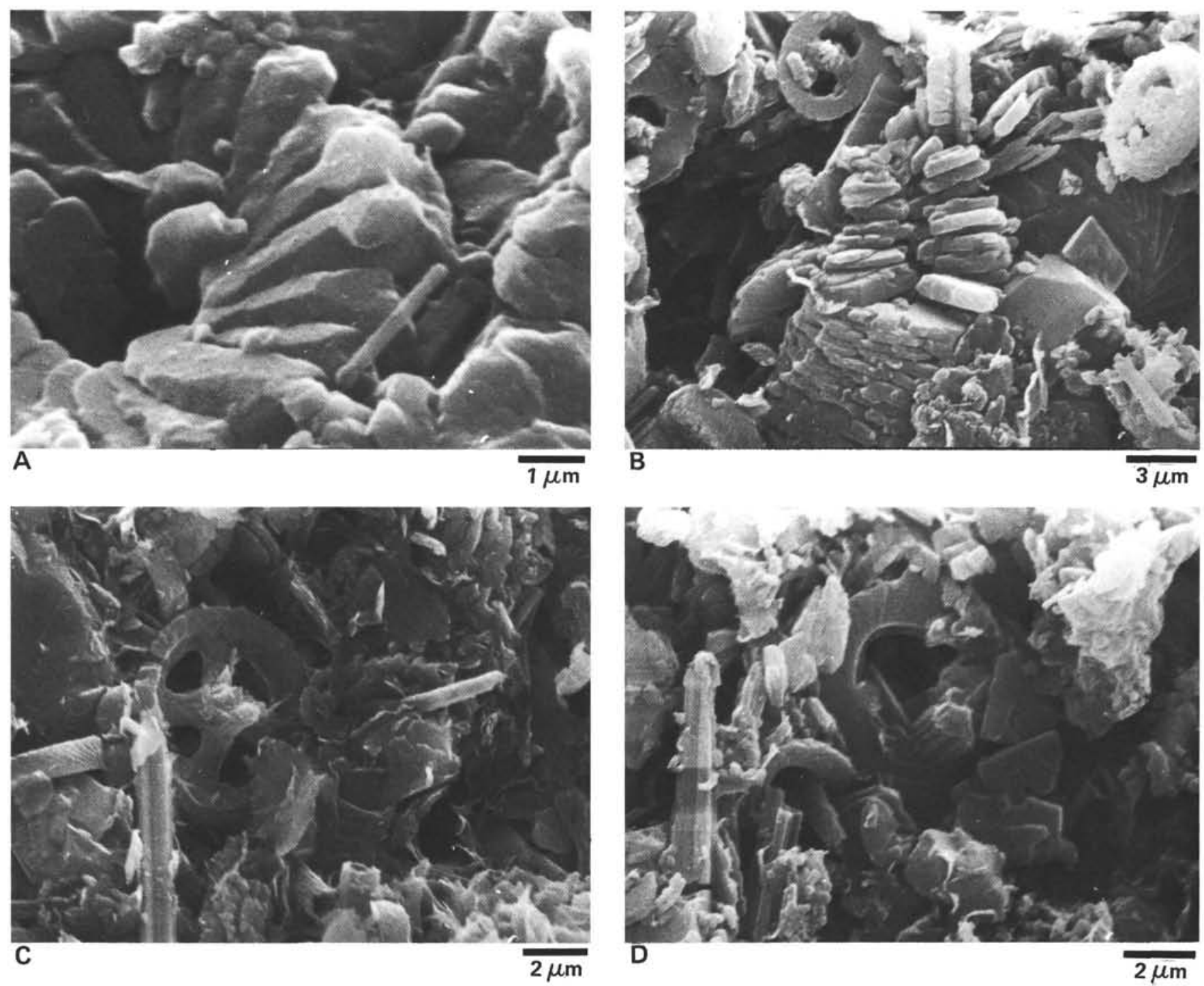

Figure 13. Scanning electron micrographs of calcareous claystones. A. Partly dissolved coccolith overgrown with calcite. B. Partly disaggregated coccolith. (A and B, Sample 534A-48-2, 165-167 cm.) C. Coccoliths at the top of the Blake-Bahama Formation are highly dissolved, and overgrown with sparry calcite. D. Calcite crystals overgrowing coccoliths. (C and D, Sample 534A-47-2, 84-86 cm.)

dinate mica, as well as other terrigenous grains and bioclastic material (Fig. 16C, D). Above Core 55 (Hauterivian) redeposited carbonate predominates over terrigenous material (Fig 16E, F); from Cores 55 through 60, these materials are approximately equal in abundance (Fig. 1), then below Core 60, terrigenous clastic material predominates (late Valanginian to Hauterivian).

Specific points of interest are shown in Table 1. Also, Core 60 , Section $2,136-137 \mathrm{~cm}$ contains $35 \%$ terrigenous clastics, including abundant biotite and muscovite; the redeposited carbonate material is again micritic. Samples contain quartz, plagioclase, polycrystalline quartz, perthite, chlorite, microline, orthoclase, rare tourmaline, and mica. Maximum extinction-angle tests show that plagioclase is in the andesine-labradorite range. More argillaceous, finer-grained, redeposited clastics contain minor glauconite (e.g., Core 61, Section $2,16-19 \mathrm{~cm})$. Cross laminations are typically picked out by muscovite laths. Pressure solution of shell fragments in contact with quartz grains is visible (Core 62, Section $1,15-17 \mathrm{~cm})$. Fine quartz and other terrigenous grains are often replaced by calcite. Unusually, in Core 52, Section 1, 71-73 cm there are several small grains of feldspathic basalt (?trachyte) and quartzose siltstone extraclasts.

Terrigenous clastics are best developed above the interval between Cores 59 and 64 (lower Hauterivian). Typical thin sections (Core 59, Section 2, 17-19 cm) contain silt-sized quartz, plagioclase, muscovite, biotite, orthoclase, chlorite, and minor hornblende, in decreasing order of abundance. Minor heavy minerals include epidote, zircon, and tourmaline. Coarser-grained (sandsized) turbidites contain, in decreasing order of abundance, quartz, fresh plagioclase, polycrystalline quartz, muscovite, biotite, microline perthite, and opaque oxides (pyrite). In these clastic sediments, true shallow- 

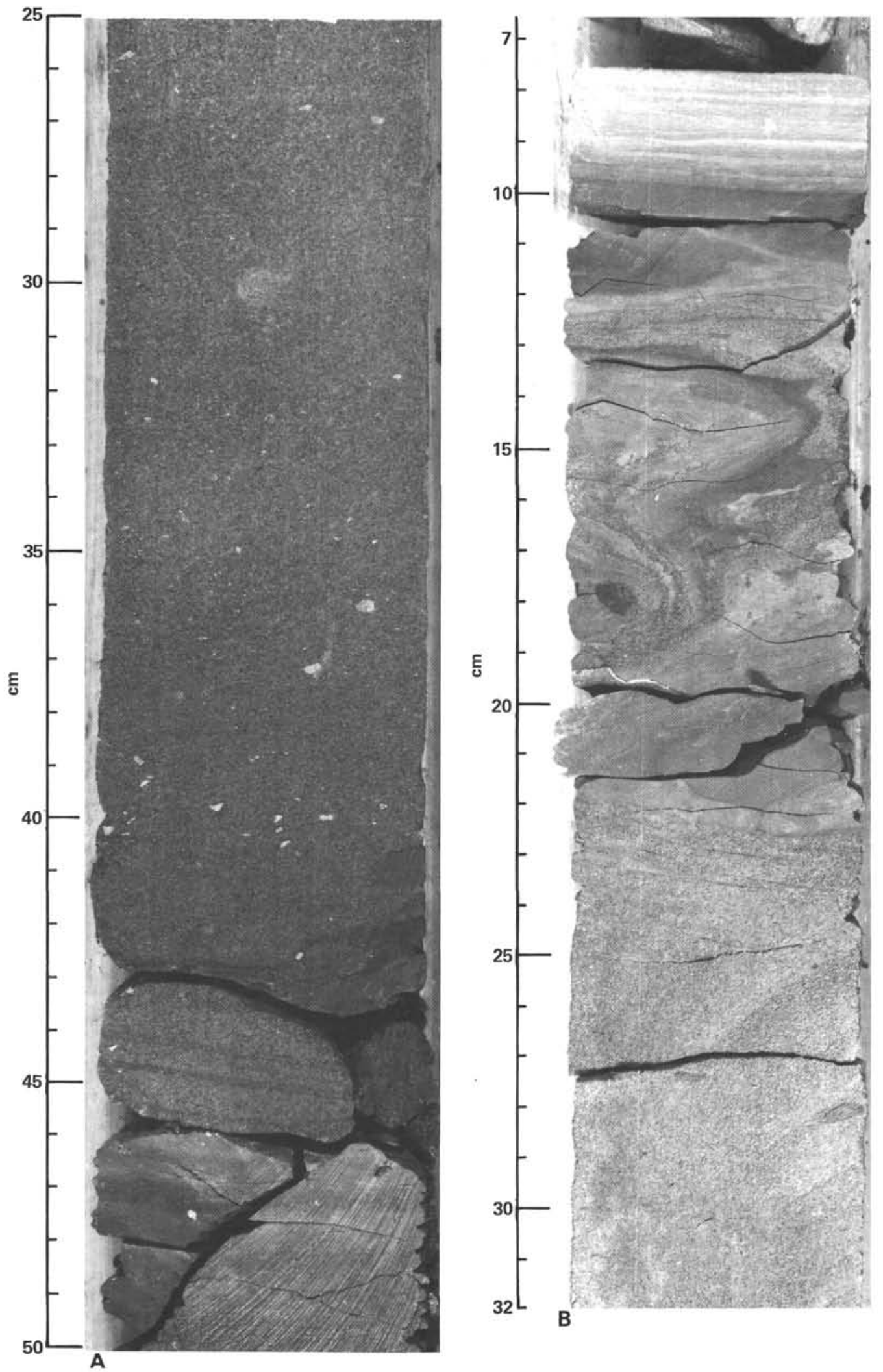

Figure 14. Core photographs of redeposited clastics. A. Base packstone calciturbidites (Core 58, Section 4, $25-50 \mathrm{~cm})$. (Note the basal rip-up mudstone intraclasts $(42-43 \mathrm{~cm}$ ), the plane-lamination, and the white particles of crystalline, shallow-water limestone.) B. Convolute-laminated interval within calciturbidites (Core 58 , Section 2, 7-32 cm). (Note that the convoluted material consists of packstone and marly nannofossil chalk seen in the intercalated beds, and does not introduce exotic material. It was probably produced by slumping off a local topographic high, possibly a channel margin.) 

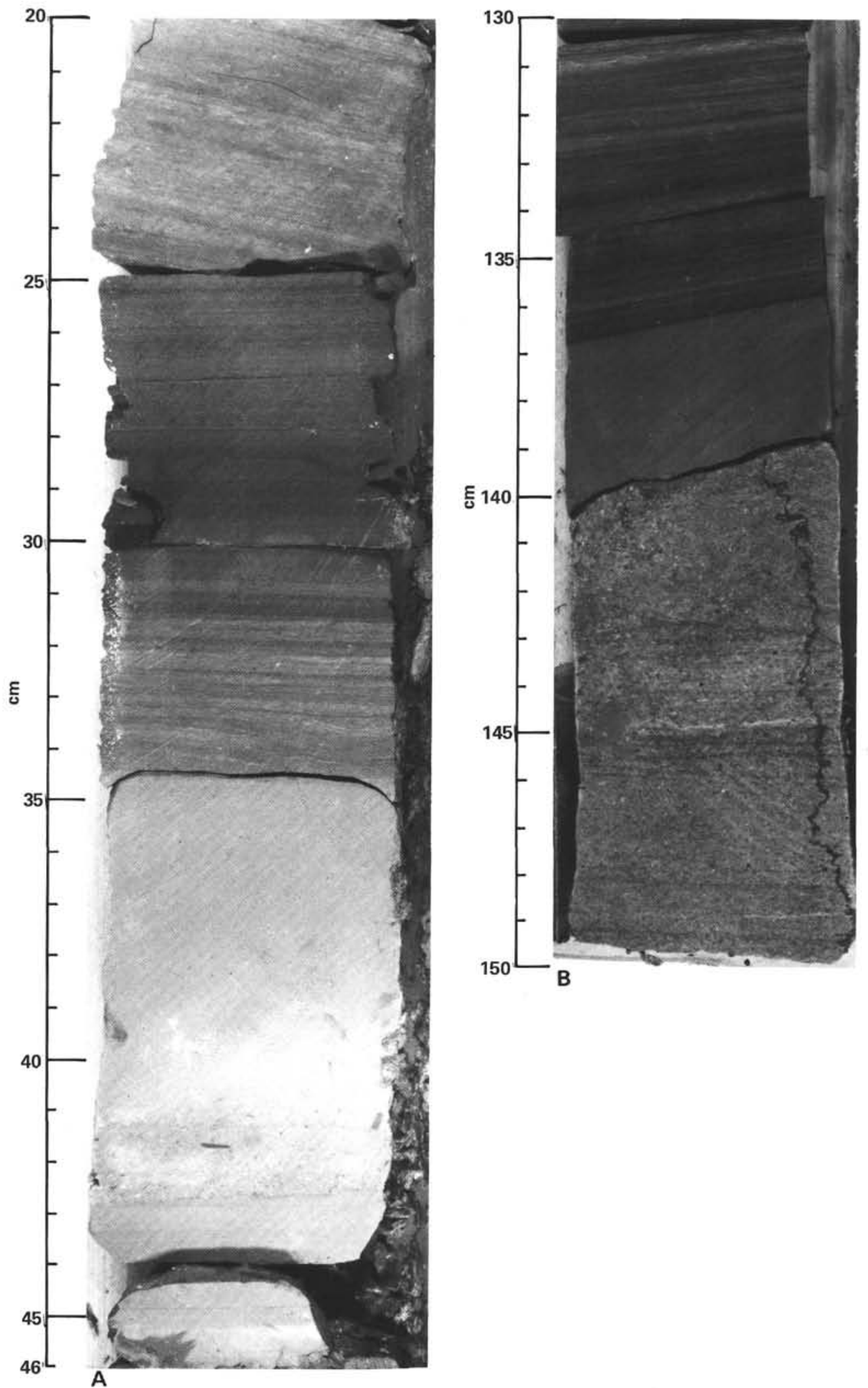

Figure 15. Core photographs of redeposited clastic facies. A. Quartz-mica bearing graded, redeposited limestone (Core 53, Section 4, 20-46 cm). (The packstone base passes up into redeposited calcilutite, then progresses into finely laminated marly nannofossil chalk. Note the relative absence of bioturbation.) B. Upper part of a mixed terrigeneous-carbonate turbidite, with a packstone texture (Core 55, Section 1, $130-150 \mathrm{~cm}$ ). (Note the plane and ripple lamination [Bouma T b, c divisions]. The upper part of the turbidite is missing, possibly a drilling artifact. Note the well-developed subvertical stylolite.) 
water carbonate material is absent (e.g., ooids, algae). Grains in the debris flow (Core 58, Section 4, 16-18 cm) include $50 \%$ quartz microcline, plagioclase and muscovite in the silt to coarse sand range; $25 \%$ crystalline carbonate grains and finely crystalline detrital spar; $25 \%$ matrix (consisting of comminuted bits of all other grain types) and intergranular pore space (Figs. 2, 3, 16).

Redeposited shallow-water carbonate materials predominate in some intervals (Core 53, Section 4, 11-13 $\mathrm{cm}$ ), with only rare scattered quartz grains (Fig. 17E, F). These clastics include shell fragments, benthic foraminifers, echinoderm plates, corraline algae, micritic intraclasts, pellets, oolitic coatings, rare ooids, and ostracode shells (Table 1).

Several of the limestones (e.g., Core 49, Section 5, $140 \mathrm{~cm}$ ) are strongly pelletoidal. Sometimes the pelletoidal texture is produced by patchy recrystallization of

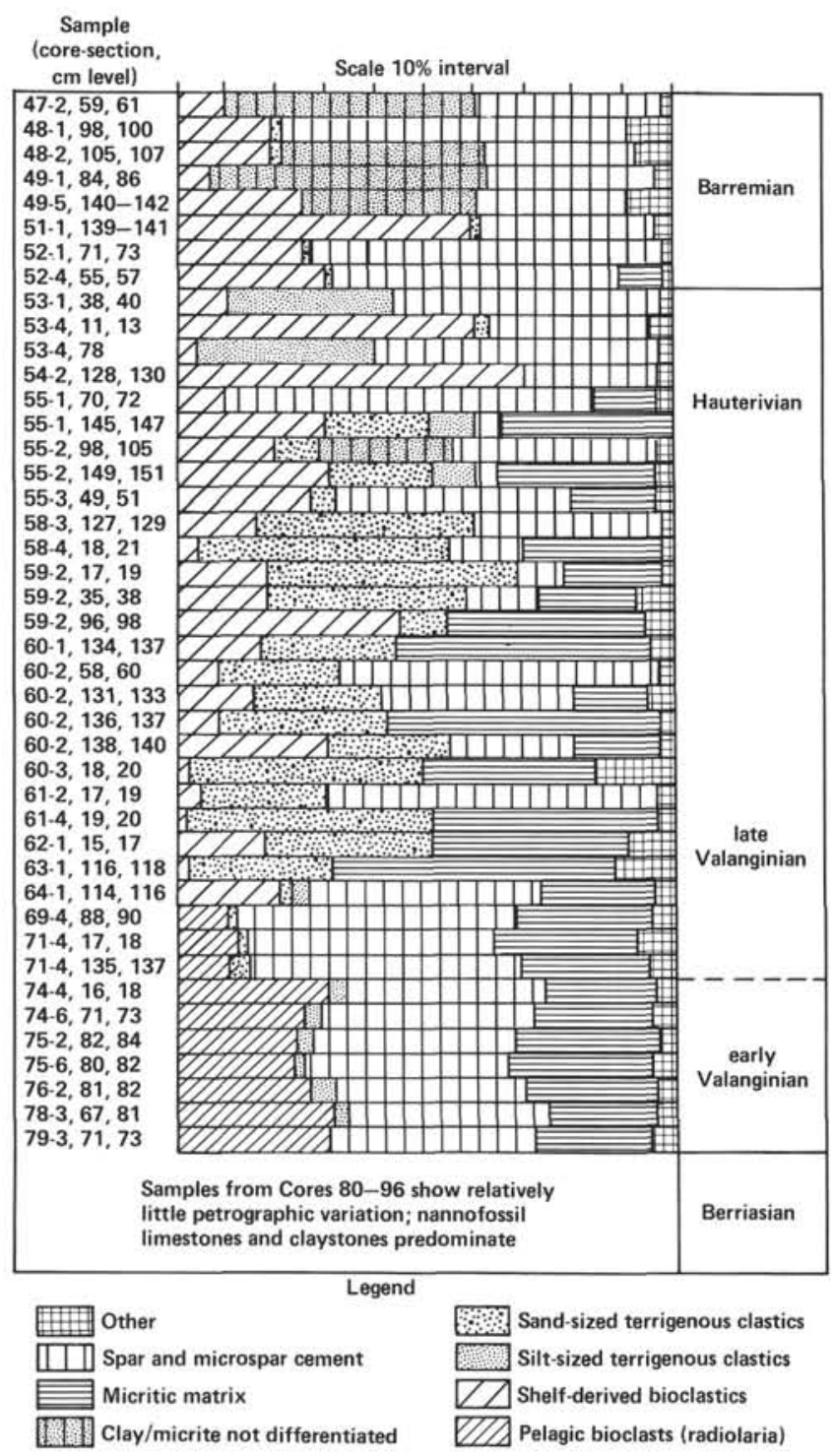

Figure 16. Summary of composition of Blake-Bahama Hole 534A lithologies examined with optical microscope. (The various categories of sediment are illustrated in the legend. The length of the bar in each case indicates the relative percentage abundance.) micrite (Core 52, Section 2, 128-130 cm). Apart from pelletoidal micrite, there are scattered grains of angular quartz, perthite, muscovite, and feldspar. Much of the bioclastic material has well developed micritic envelopes and is otherwise extensively micritized. Where present the micritic matrix is largely converted to microspar; pore spaces are filled with sparry calcite. In addition, some intervals (e.g., Core 55, Section 1, 145-146 cm) contain rare pisoliths and echinoderm plates. Below Core 54 (Hauterivian), most of the redeposited limestones are micritic rather than packstones (Core 59, Section 2, 22-24 cm) and contain micritic intraclasts, pellets, benthic foraminifers, echinoderm plates, shell fragments, and radiolarians, but no shallow material such as ooids or corraline algae.

Scanning electron micrographs of the redeposited terrigenous and carbonate facies show conchoidally fractured detrital grains (Fig. 18C), sparry calcite (Fig. 18B), crystals that may be dolomite (Fig. 18A), and some less easily interpreted fabrics (Fig. 18D).

\section{X-RAY DIFFRACTION}

As a pilot study, 15 samples (less than the $20-\mu \mathrm{m}$ fraction) of Blake-Bahama Formation rocks were subjected to X-ray diffraction as whole-rock samples, and then treated with ethylene glycol. More clay mineral data are given by Chamley et al. (this volume).

Samples of nannofossil limestones (e.g., Core 68, Section 4, 46-58 cm), containing abundant radiolarians, consist mineralogically of quartz and calcite with little detectable clay mineral content. The graded turbidite claystones are dominated by smectite, with relatively abundant mixed-layer clays, and small amounts of chlorite and palygorskite, in addition to quartz and calcite (e.g., Core 58, Section 1, 130-132 cm). Claystone (e.g., Core 69 , Section $1,88-90 \mathrm{~cm}$ ), which in thin section is seen to contain abundant fine-grained quartz and mica, also contains abundant feldspar, as determined by X-ray diffraction.

The dark, laminated, carbonaceous, marly, nannofossil chalks possess clay minerals similar to those of the claystone, although with much lower clay content. One sample (less than $20 \mu \mathrm{m}$, Core 50 , Section $4,54-56 \mathrm{~cm}$ ) contains smectite, mixed-layer clays, kaolinite, and abundant feldspar. A sample from Core 49, Section 1, 84-86 $\mathrm{cm}$ is almost identical. By contrast, samples of the paler gray, finely laminated marly chalk (e.g., Core 80 , Section $5,126-128 \mathrm{~cm}$ ) contain relatively little clay, mostly smectite, with traces of mixed-layer clays and pyrite. Feldspars are not detected. A sample of dark gray laminated claystone from Core 92 , Section $5,37-39 \mathrm{~cm}$ is similar.

As seen in thin section, the terrigenous turbidite siltstones and fine sandstones possess abundant feldspar, but relatively low concentrations of clay minerals, principally smectite and mixed-layer clays (e.g., Core 58, Section 3, 124-126 cm and Core 59, Section 2, 96-98 $\mathrm{cm})$.

In summary, illite, with subordinate mixed-layer clays, dominate the claystones and argillaceous dark carbonaceous nannofossil marly chalks, whereas the pale gray 

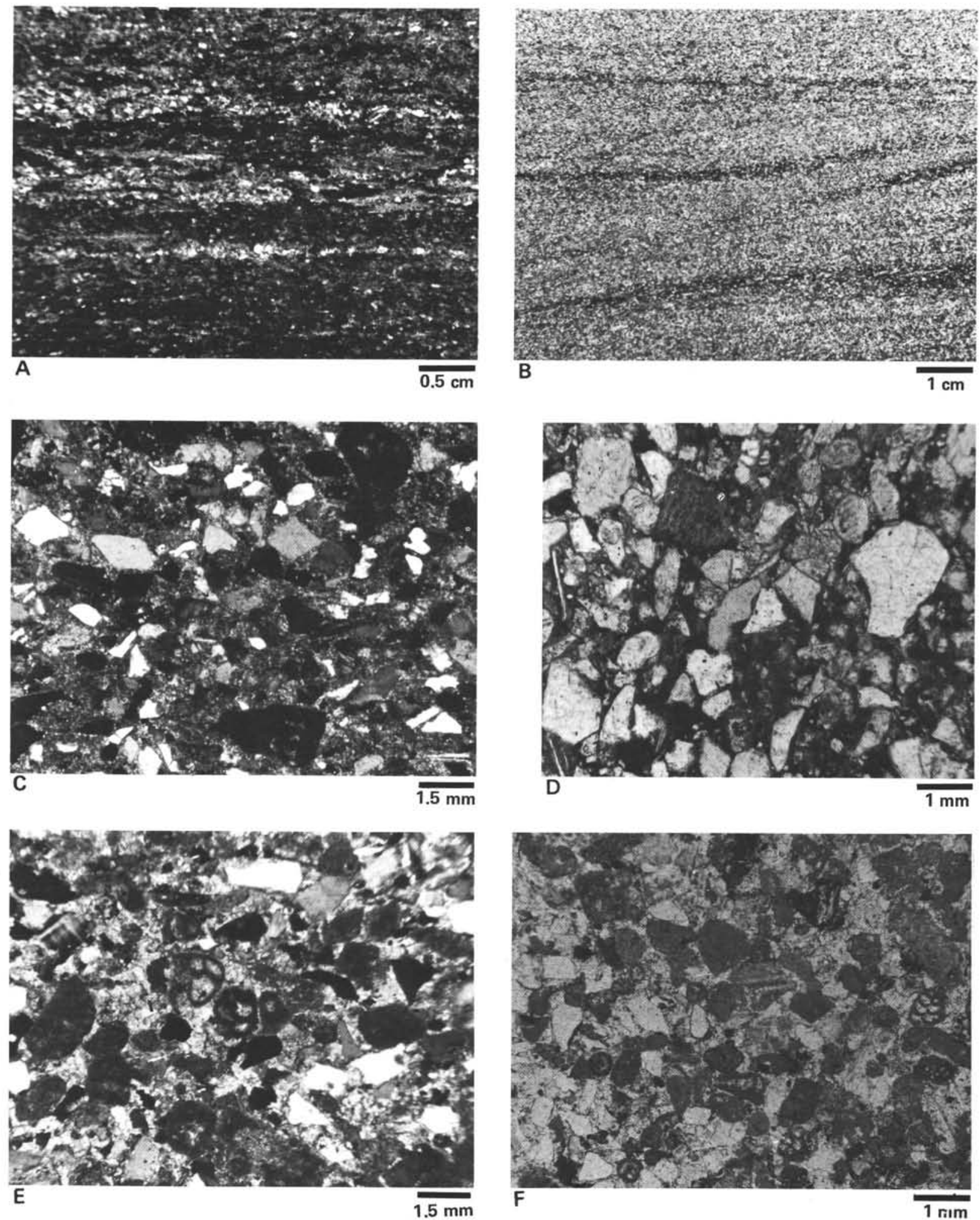

Figure 17. Photomicrographs of redeposited Blake-Bahama lithologies. A. Laminated quartzose siltstone (Core 69, Section 7, 7-10 $\mathrm{cm}$ ). (Note stringers of quartz grains [light and dark flakes, clay, and micas].) B. Cross lamination in redeposited quartzose turbidite; laminations (dark) are mostly picked out by micas (Core 59, Section 2, 22-24 cm). (This example is mostly terrigenous with little redeposited carbonate material) C. Relatively coarse-grained quartzose turbidite (Core 58, Section 3, 124-126 cm). (Note angular immature grains mostly of quartz and fine-grained matrix dominated by sparry calcite.) D. This sample is similar, but the quartz fabric is more tightly packed with less matrix (Core 61 , Section $4,116-118 \mathrm{~cm}$ ). (Base of turbidite bed. Note the elongate mica flakes and the claystone rip-up clasts [dark].) E, F. Redeposited shallow-water carbonate material. (Note the benthic foraminifers, oolitic coated grains, micritic intraclasts, as well as scattered quartz grains. (E, Core 54, Section 3, 49-51 cm; F, Core 51, Section 1, 139-141 cm. All plane-polarized light except 17-F, which is under crossed-nicols.) 


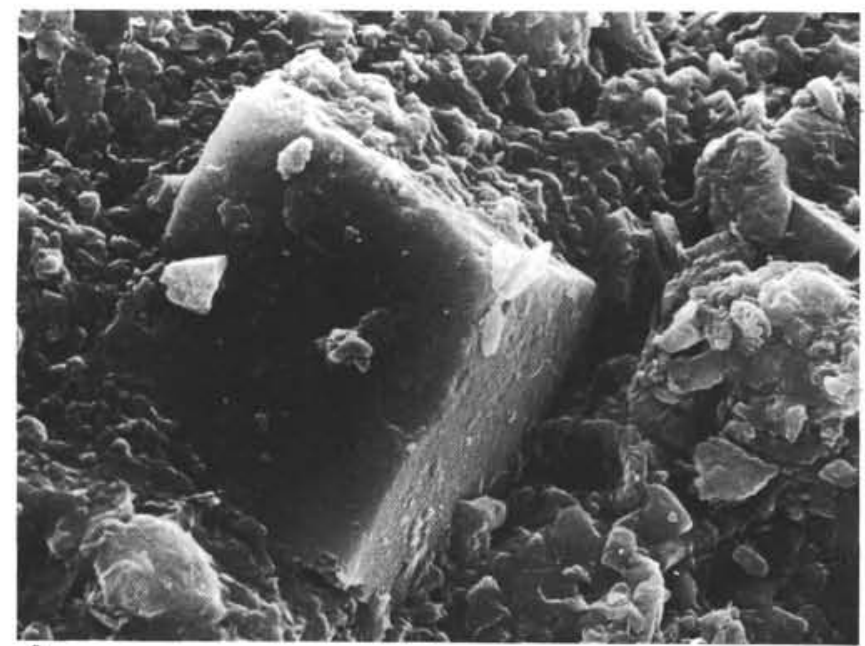

A

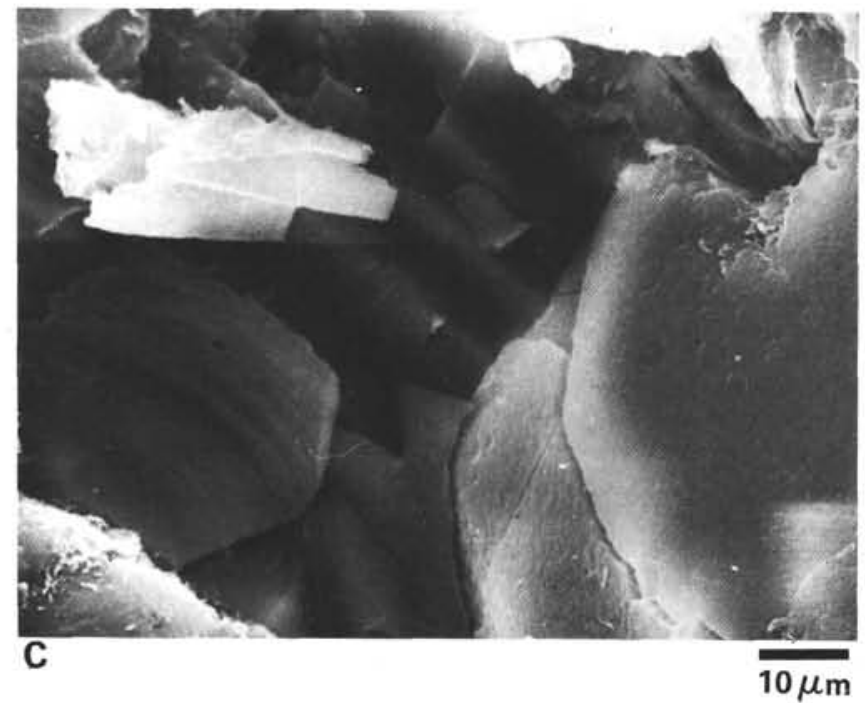

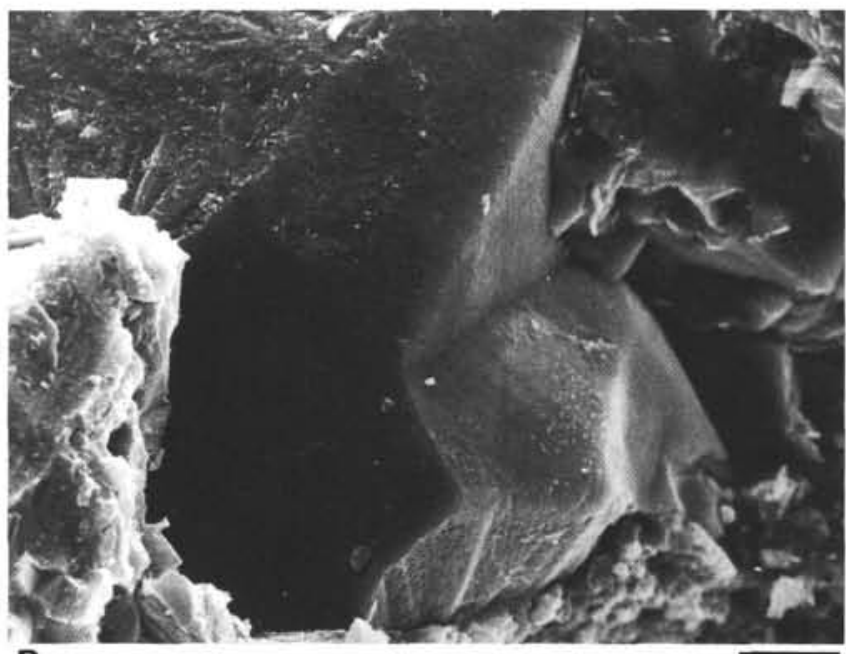

B

$20 \mu \mathrm{m}$

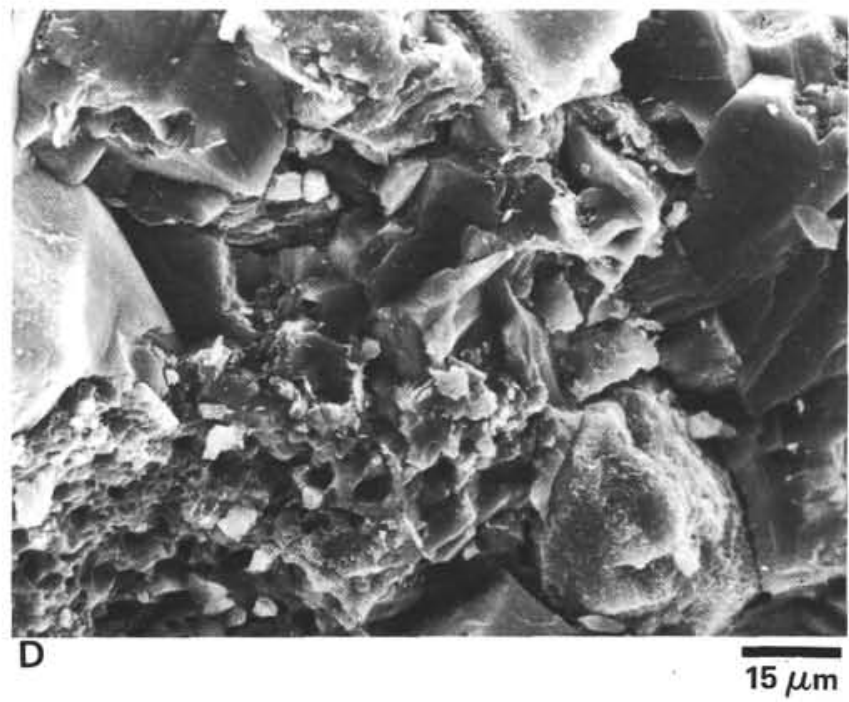

Figure 18. Scanning electron micrographs of redeposited clastics (Core 63, Section 1, 118-119 cm). A. ?Dolomite rhomb within bioclastic limestones (thin section). B. Large sparry calcite crystal probably cemented. C. Conchoidally fractured terrigenous grains (?quartz), lower left, in bioclastic redeposited limestone. D. Typical fabric of redeposited bioclastics.

laminated marly chalks and nannofossil limestones contain low clay mineral abundances.

\section{Chemistry}

Analyses of nitrogen, organic carbon, and $\mathrm{CaCO}_{3}$ (by the BOMB method) carried out at sea and on shore are given in Tables 2 and 3. The highest organic carbon values recorded on the ship come from dark marly claystone (2.05-3.86\%) from the top of the Barremian succession transitional to the Hatteras Formation (Table 2). Other dark claystones lower in the sequence contain organic carbon values over $1 \%$ (e.g., $1.68 \%$ in Core 73 near the top of the lower Valanginian succession). One of the dark clastic turbidites from the Hauterivian of Core 60 also shows relatively high carbon values of $1.34 \%$. By contrast, paler graded calcareous claystones exhibit lower organic carbon values (e.g., $0.47 \%$ in Core 58 , Hauterivian). Organic carbon values in the pale laminated marly nannofossil chalks, burrowed marly nan- nofossil chalks, and limestones fall below $0.7 \%$ (e.g., Core $54,0.25 \%$ ). Shore-based laboratory results are given in Table 3.

The shipboard and shore-based laboratory analyses of $\mathrm{CaCO}_{3}$ by the BOMB method confirm the calcareous nature of all the Blake-Bahama sediments, as well as the fall in $\mathrm{CaCO}_{3}$ levels at the top of the Barremian succession. The results also confirm the presence of $>10 \%$ of non- $\mathrm{CaCO}_{3}$ in most of the Blake-Bahama pelagic carbonates, which should thus be termed "marly" in DSDP terminology. More specifically, in Core 89 a limestone was sampled next to a clay seam to compare $\mathrm{CaCO}_{3}$ content. Next to the stylolite (Core 89, Section 3, $20 \mathrm{~cm}$ ) gave $88 \% \mathrm{CaCO}_{3}$. The stylolite was present in limestone with an atypically low clay content. In the normal, more clay-rich pelagic carbonates, more abundant clay blocks carbonate pressure solution, which explains why stylolites only occur rarely in the purest Blake-Bahama limestones. 
Table 2. $\mathrm{C}, \mathrm{N}$, and $\mathrm{CaCO}_{3}$ values for Hole 534A Blake-Bahama Formation sediments determined on board the Glomar Challenger.

\begin{tabular}{clcccc}
\hline $\begin{array}{c}\text { Sample } \\
\text { no. }\end{array}$ & $\begin{array}{c}\text { Sample } \\
\text { (core-section, } \\
\text { interval in cm) }\end{array}$ & $\begin{array}{c}\mathrm{N} \\
(\%)\end{array}$ & $\begin{array}{c}\text { C-organic } \\
(\%)\end{array}$ & $\mathrm{C} / \mathrm{N}$ & $\begin{array}{c}\mathrm{CaCO}_{3} \\
(\mathrm{BOMB}) \\
(\%)\end{array}$ \\
\hline 88 & $47-1,94-96$ & 0.08 & 2.05 & 30.2 & 21.0 \\
89 & $48-1,111-113$ & 0.19 & 3.86 & 23.6 & 20.5 \\
90 & $49-7,11-13$ & 0.04 & 0.85 & 24.4 & 31.9 \\
91 & $50-1,70-41$ & 0.04 & 0.99 & 28.6 & 32.9 \\
92 & $52-3,7-8$ & 0.04 & 1.20 & 34.7 & 55.2 \\
93 & $53-2,105-106$ & 0.04 & 0.64 & 18.9 & 34.4 \\
94 & $54-1,102-104$ & 0.01 & 0.25 & 19.5 & 78.9 \\
95 & $55-2,76-78$ & 0.03 & 0.67 & 24.3 & 35.3 \\
96 & $56-2,45-47$ & 0.05 & 1.02 & 25.5 & 22.5 \\
97 & $58-1,88-90$ & 0.05 & 0.48 & 10.7 & 35.8 \\
98 & $59-3,74-76$ & 0.04 & 1.02 & 30.5 & 34.8 \\
99 & $60-4,105-106$ & 0.08 & 1.34 & 19.0 & 17.8 \\
103 & $64-3,45-47$ & 0.05 & 0.92 & 22.3 & 19.3 \\
108 & $69-2,105-107$ & 0.03 & 0.77 & 26.5 & 32.3 \\
112 & $73-3,115-116$ & 0.06 & 1.68 & 32.0 & 49.2 \\
117 & $78-1,63-64$ & 0.04 & 1.00 & 27.2 & 14.3 \\
122 & $83-2,53-54$ & 0.04 & 0.56 & 17.5 & 73.1 \\
\hline
\end{tabular}

To augment data given by Murdmaa et al. (1978) for the Blake-Bahama Formation, eight samples of nannofossil marly chalks, claystones, siltstones, and quartzose sandstones were analyzed for major elements, using a method previously described by Norrish and Hutton (1969). In addition, two samples of dark carbonaceous mudstones were analyzed from the base of the Hatteras Formation for comparison. Raw data are shown in Table 4 . Graphs showing major element relationships are plotted in Fig. 19.

The nannoplankton claystones contain the greatest abundances of $\mathrm{Al}_{2} \mathrm{O}_{3}(14.7-16.5 \%), \mathrm{K}_{2} \mathrm{O}(2.7-2.9 \%)$, $\mathrm{MgO}(3.5-4.0 \%)$, and $\mathrm{TiO}_{2}(0.7-0.8 \%)$, but the lowest values of $\mathrm{MnO}(0.28-0.33 \%)$. The darker laminated marly nannofossil chalks are richer in $\mathrm{Al}_{2} \mathrm{O}_{3}, \mathrm{MgO}$, $\mathrm{K}_{2} \mathrm{O}$, and $\mathrm{TiO}_{2}$ than the paler laminated marly nannofossil chalks. One sample of fine-grained quartzose sandstone and one of argillaceous mudstone are plotted for comparison.

Plots of ratios, rather than absolute values of oxide abundance, help identify provenance. In all samples a good correlation exists between $\mathrm{Al}_{2} \mathrm{O}_{3}$ and $\mathrm{TiO}_{2}$, implying that all the samples could derive from similar terrigenous source rocks. The ratio of $\mathrm{Al}_{2} \mathrm{O}_{3} / \mathrm{TiO}_{2}$ (ca. 20:1) applies to both the paler and darker, more carbonaceous laminated claystones. Similarly, all the laminated marly chalks show correlations of $\mathrm{Al}_{2} \mathrm{O}_{3}$ and $\mathrm{Fe}_{2} \mathrm{O}_{3}$, but the sample of quartzose sandstone shown in Figure 19 plots away from the average ratio $\left(\mathrm{Al}_{2} \mathrm{O}_{3} / \mathrm{Fe}_{2} \mathrm{O}_{3}\right.$, ca. 1.8:1), possibly because the turbiditic sandstones contain more undegraded alumino-silicate (e.g., muscovite) than the marly nannofossil chalks. None of the samples analyzed contain significant amounts of pyrite in thin section.

Good correlations also exist between $\mathrm{Al}_{2} \mathrm{O}_{3}$ and $\mathrm{MgO}$ (Fig. 19), reflecting the abundance of clays $\left(\mathrm{Al}_{2} \mathrm{O}_{3} / \mathrm{K}_{2} \mathrm{O}\right.$, $7: 1 ; \mathrm{Al}_{2} \mathrm{O}_{3} / \mathrm{MgO}$, ca. 9.5:1). Only the sample of quartzose siltstone has a significantly different $\mathrm{Al}_{2} \mathrm{O}_{3} / \mathrm{K}_{2} \mathrm{O}$ ratio, reflecting the abundance of muscovite laths, seen in thin section. The samples of marly nannofossil chalk,
Table 3. Shore-based determination of $\mathrm{C}$ and $\mathrm{CaCO}_{3}$ values for Hole 534A, Blake-Bahama Formation sediments.

\begin{tabular}{|c|c|c|c|c|}
\hline $\begin{array}{c}\text { Sample } \\
\text { (core-section, } \\
\text { interval in cm) }\end{array}$ & $\begin{array}{c}\text { Sub- } \\
\text { bottom } \\
\text { depth } \\
\text { (m) }\end{array}$ & $\mathrm{CaCO}_{3}$ & Total & $\begin{array}{l}\text { Organic } \\
\text { carbon }\end{array}$ \\
\hline $47-1,20$ & 950.20 & 33.919 & 6.9 & 2.8 \\
\hline $47-2,129$ & 952.79 & 93.523 & 11.4 & 0.1 \\
\hline $48-0,97$ & 959.87 & 31.073 & 6.0 & 2.3 \\
\hline $48-1,50$ & 959.50 & 93.316 & 11.5 & 0.3 \\
\hline $48-4,97$ & 954.37 & 31.073 & 6.0 & 2.3 \\
\hline $49-4,93$ & 968.83 & 45.768 & 7.2 & 1.8 \\
\hline $49-5,61$ & 970.11 & 91.677 & 11.5 & 0.5 \\
\hline $50-1,45$ & 972.95 & 34.358 & 5.5 & 1.4 \\
\hline $50-3,49$ & 975.99 & 85.737 & 10.8 & 0.5 \\
\hline $51-1,7$ & 981.57 & 38.610 & 5.4 & 0.8 \\
\hline $52-2,53$ & 992.53 & 50.850 & 6.9 & 0.8 \\
\hline $52-4,104$ & 996.04 & 88.359 & 11.3 & 0.6 \\
\hline $53-1,104$ & 1000.54 & 92.170 & 11.2 & 0.1 \\
\hline $53-4,26$ & 1004.26 & 37.030 & 5.8 & 1.4 \\
\hline $54-1,70$ & 1009.20 & 74.957 & 9.7 & 0.7 \\
\hline $54-1,136$ & 1009.86 & 88.480 & 10.8 & 0.2 \\
\hline $55-3,0$ & 1020.50 & 90.839 & 11.1 & 0.2 \\
\hline $55-3,54$ & 1021.04 & 80.801 & 10.3 & 0.6 \\
\hline $56-1,53$ & 1027.03 & 75.198 & 9.6 & 0.6 \\
\hline $56-2,50$ & 1028.50 & 57.080 & 8.2 & 1.4 \\
\hline $58-1,90$ & 1045.40 & 38.806 & 5.2 & 0.5 \\
\hline $58-4,21$ & 1049.21 & 28.206 & 1.5 & 0.1 \\
\hline $59-1,13$ & 1053.63 & 41.469 & 5.1 & 0.1 \\
\hline $59-2,89$ & 1055.09 & 74.461 & 9.7 & 0.8 \\
\hline $60-1,112$ & 1063.62 & 93.875 & 11.4 & 0.1 \\
\hline $60-4,103$ & 1068.03 & 20.864 & 3.7 & 1.2 \\
\hline $61-1,101$ & 1072.51 & 14.423 & 3.0 & 1.3 \\
\hline $86-3,62$ & 1289.62 & 84.321 & 10.2 & 0.1 \\
\hline $87-1,33$ & 1295.33 & 87.595 & 10.6 & 0.1 \\
\hline $87-4,20$ & 1299.70 & 85.989 & 10.4 & 0.1 \\
\hline $88-1,20$ & 1304.20 & 90.444 & 10.9 & 0.1 \\
\hline $88-4,20$ & 1308.70 & 92.025 & 11.1 & 0.1 \\
\hline $89-3,20$ & 1316.20 & 94.812 & 11.5 & 0.1 \\
\hline $89-4,20$ & 1317.70 & 88.102 & 10.6 & 0.1 \\
\hline $90-1,107$ & 1323.07 & 77.391 & 9.4 & 0.1 \\
\hline $90-4,149$ & 1327.99 & 51.047 & 6.3 & 0.2 \\
\hline $91-1,32$ & 1331.32 & 90.655 & 10.9 & 0.1 \\
\hline $91-4,63$ & 1336.13 & 87.513 & 10.5 & 0.0 \\
\hline
\end{tabular}

which lie outside the typical ratios of $\mathrm{Al}_{2} \mathrm{O}_{3} / \mathrm{MgO}$, are all highly calcareous (46-69\%) and could reflect the existence of high-magnesian calcites or some dolomite. One sample from the base of the Hatteras Formation, associated with black carbonaceous shales, shows the highest observed $\mathrm{MnO}$ value of $0.15 \%$. Samples of the most calcareous marly nannofossil chalks exhibit the lowest $\mathrm{MnO}$ values $(0.02-0.03 \%)$. In contrast to the other oxides, $\mathrm{P}_{2} \mathrm{O}_{5}$ values show no correlation with $\mathrm{Al}_{2} \mathrm{O}_{3}$ values, presumably confirming that phosphate is not related to terrigenous input, but is mostly biogenic in origin.

\section{DIAGENESIS}

The Blake-Bahama rocks have experienced seafloor and, to some extent, burial diagenesis. The main diagenetic features from the base of the formation upward are summarized next.

The Berriasian Subunit 5d, with abundant bioturbated intervals, is also dominated by well-cemented limestones. Stylolites that appeared in Subunit 5c, are more 
Table 4. Major element composition of Hole 534A laminated nannofossil chalks and claystones from the Blake-Bahama Formation.

\begin{tabular}{|c|c|c|c|c|c|c|c|c|c|c|}
\hline $\begin{array}{l}\text { Analysis no. } \\
\text { Sample } \\
\text { (core-section, } \\
\text { interval in cm) } \\
\text { Type } \\
\text { Formation } \\
\text { (age) } \\
\end{array}$ & $\begin{array}{c}1 \\
42-1,83-85 \\
\text { Mudstone } \\
\text { Hatteras } \\
\text { (Aptian) }\end{array}$ & 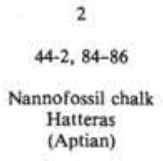 & $\begin{array}{c}3 \\
\begin{array}{c}\text { 47-2, 59-61 } \\
\text { Nannofossil chalk } \\
\text { Blake-Bahama } \\
\text { (Berriasian) }\end{array}\end{array}$ & $\begin{array}{c}4 \\
\begin{array}{c}\text { 49-4, 84-86 } \\
\text { Nannofossil chalk } \\
\text { Blake-Bahama } \\
\text { (Berriasian) }\end{array}\end{array}$ & $\begin{array}{c}5 \\
\text { 58-1, 130-132 } \\
\text { Gray claystone } \\
\begin{array}{c}\text { Blake-Bahama } \\
\text { (Hauterivian) }\end{array}\end{array}$ & $\begin{array}{c}6 \\
59-2,96-98 \\
\begin{array}{c}\text { Micaceous sandstone } \\
\text { Blake-Bahama } \\
\text { (Hauterivian) }\end{array}\end{array}$ & $\begin{array}{c}7 \\
61-4,116-118 \\
\begin{array}{c}\text { Claystone } \\
\text { Blake-Bahama } \\
\text { (Hauterivian) }\end{array}\end{array}$ & $\begin{array}{c}8 \\
\text { 69-1, 88-90 } \\
\text { Claystone } \\
\text { Blake-Bahama } \\
\text { (Barremian) }\end{array}$ & $\begin{array}{c}9 \\
72-3,5-7 \\
\begin{array}{c}\text { Nannofossil chalk } \\
\text { Blake-Bahama } \\
\text { (Barremian) }\end{array}\end{array}$ & $\begin{array}{c}10 \\
80-5,126-128 \\
\begin{array}{c}\text { Nannofossil limestone } \\
\text { Blake-Bahama } \\
\text { (Barremian) }\end{array}\end{array}$ \\
\hline \multicolumn{11}{|l|}{ Component } \\
\hline $\mathrm{SiO}_{2}$ & 70.75 & 37.86 & 16.26 & 42.72 & 30.10 & 48.02 & 58.05 & 60.25 & 58.67 & 38.08 \\
\hline $\mathrm{Al}_{2} \mathrm{O}_{3}$ & 13.48 & 11.20 & 2.47 & 11.29 & 8.72 & 8.62 & 15.87 & 16.51 & 14.72 & 6.89 \\
\hline $\mathrm{Fe}_{2} \mathrm{O}_{3}$ & 7.49 & 5.63 & 2.08 & 5.95 & 4.46 & 2.19 & 6.55 & 6.77 & 6.58 & 3.77 \\
\hline $\mathrm{MgO}^{2}$ & 2.52 & 1.73 & 1.90 & 2.46 & 3.05 & 0.95 & 4.00 & 4.02 & 3.56 & 1.64 \\
\hline $\mathrm{CaO}$ & 0.60 & 38.16 & 75.83 & 33.68 & 49.00 & 34.37 & 10.35 & 7.41 & 11.56 & 47.15 \\
\hline $\mathrm{Na}_{2} \mathrm{O}$ & 1.56 & 1.25 & 0.09 & 1.09 & 0.73 & 1.73 & 1.36 & 1.85 & 1.37 & 0.53 \\
\hline $\mathrm{K}_{2} \mathrm{O}$ & 2.63 & 1.72 & 0.19 & 1.55 & 1.37 & 2.50 & 2.91 & 2.96 & 2.73 & 0.84 \\
\hline $\mathrm{TiO}_{2}$ & 0.65 & 0.57 & 0.11 & 0.51 & 0.43 & 0.35 & 0.73 & 0.84 & 0.73 & 0.32 \\
\hline Mnô & 0.03 & 0.15 & 0.10 & 0.04 & 0.07 & 0.07 & 0.03 & 0.03 & 0.02 & 0.03 \\
\hline $\mathrm{P}_{2} \mathrm{O}_{5}$ & 0.03 & 0.10 & 0.09 & 0.15 & 0.04 & 0.07 & 0.05 & 0.06 & 0.05 & 0.09 \\
\hline Total & 99.80 & 98.40 & 99.15 & 99.48 & 98.00 & 98.92 & 99.94 & 100.73 & 100.03 & 99.38 \\
\hline
\end{tabular}

abundant and better developed in 5d (Fig. 4A). The dominant cement in this and other subunits is a micritic cement that is difficult to discern from the finely comminuted skeletal debris even in SEM (Fig. 9B). This micrite is partly recrystallized to microspar and rarely to finely crystalline spar (Fig. 9D). Occasionally, the diagenetic precipitation of calcite has produced intervals of a few centimeters thickness with a micronodular texture. The micrite and microspar have occluded most of the porosity in this subunit. The whispy and anastomosing interbeds of green clay (frequently millimeters in thickness, but occasionally reaching centimeters) are much more poorly cemented (Fig. 4B), more porous, and have taken up much of the deformation caused by cementation of the limestones by compacting. Evidence of deformation in the limestones is limited to brittle fracturing and microfaults (Fig. 4B). Nodules of replacement chert, up to $5 \mathrm{~cm}$ in diameter, occur in this subunit, indicating the silica from dissolution of radiolarians was retained within the sediment long enough to favour the diagenetic formation of chert nodules.

The upper Berriasian to lower Valanginian (Subunit 5c) consists of limestone intercalations in a predominantly marly nannofossil chalk succession. The somewhat cleaner (more calcareous) and less organic, bioturbated sections are preferentially cemented (Fig. 7B). That this cementation occurred relatively early is indicated by the spherical radiolarians found in these intervals (Fig. 8A). Radiolarians in laminated chalks both above and below the cemented intervals are flattened, indicating that compaction preceded cementation. The difference in time and amount of lithification can be correlated with the relative abundance of clay, which is known to retard diagenetic cementation. Throughout all the Subunits 5a through d, radiolarians are abundant, and yet, chert is rare. This indicates that the dissolution of the radiolarians occurred near the sediment/water interface and the silica was lost to seawater before chert had a chance to form.

Much of the Valanginian interval (Subunit 5b) shows predominantly near-surface diagenesis with less evidence of deeper burial. Bottom conditions were oxidizing more often, and bioturbation is more widespread. Utilization of organic matter by burrowers may have been an important factor in the color (as well as sedimentary structure) segregation of the lighter, bioturbated inter- vals (little organic matter) from the darker, laminated intervals (abundant organic matter). Compaction has come into play in this less well-cemented interval, and radiolarians are frequently elliptical (Fig. 8F). After the silica dissolved, the radiolarians were flattened before sparry-calcite filled the molds. Dolomite rhombs are rare and probably reflect a localized source of $\mathrm{Mg}$ released by dissolution of high-magnesian calcite shells.

The Hauterivian-Barremian interval (Subunit 5a), which consists of finely laminated chalks, quartzose turbidites, and calcareous claystones, exhibits many of the diagenetic features also seen lower in the formation. Grains are either micritized (usually shallow-water carbonate grains) or dissolved (including radiolarians and bivalves). Rare bioturbation (Fig. 8D) indicates that bottom conditions, if not reducing, were at least borderline. This fostered the existence of anaerobic conditions just below the sediment/water interface, which lead to pyritization of radiolarians (Fig. 8B, C) and formation of small pyrite nodules shortly after deposition. The molds of dissolved grains were almost immediately filled with calcite, as there is no deformation or breakage of grains. After burial, diagenesis continued, with the main processes being recrystallization of micrite to microspar and the filling of pore spaces with finely crystalline sparry calcite cement.

\section{Carbon and Oxygen Isotopic Analyses}

Analyses of $\delta \mathrm{O}^{18}$ and $\delta \mathrm{C}^{13}$ can be used to categorize environments of lithification (e.g., Hudson, 1977). Isotopic values of Blake-Bahama sediments obtained in this study are given in Table 5 , then plotted both against each other (Fig. 20) and against depth (Figs. 21, 22). No systematic changes are seen in these plots. This information indicates that there has been little change in water temperature or migration of carbon, and that the diagenetic products were formed in a fairly closed system such that their composition is nearly the same as their original constituents.

\section{REGIONAL COMPARISONS}

\section{Blake-Bahama Basin, Site 391}

A similar succession was drilled at Site 391 on Leg 44 (Benson, Sheridan et al., 1978, Fig. 1). Four subunits were recovered (c.f., $268 \mathrm{~m}$ at Site 533), which corre- 

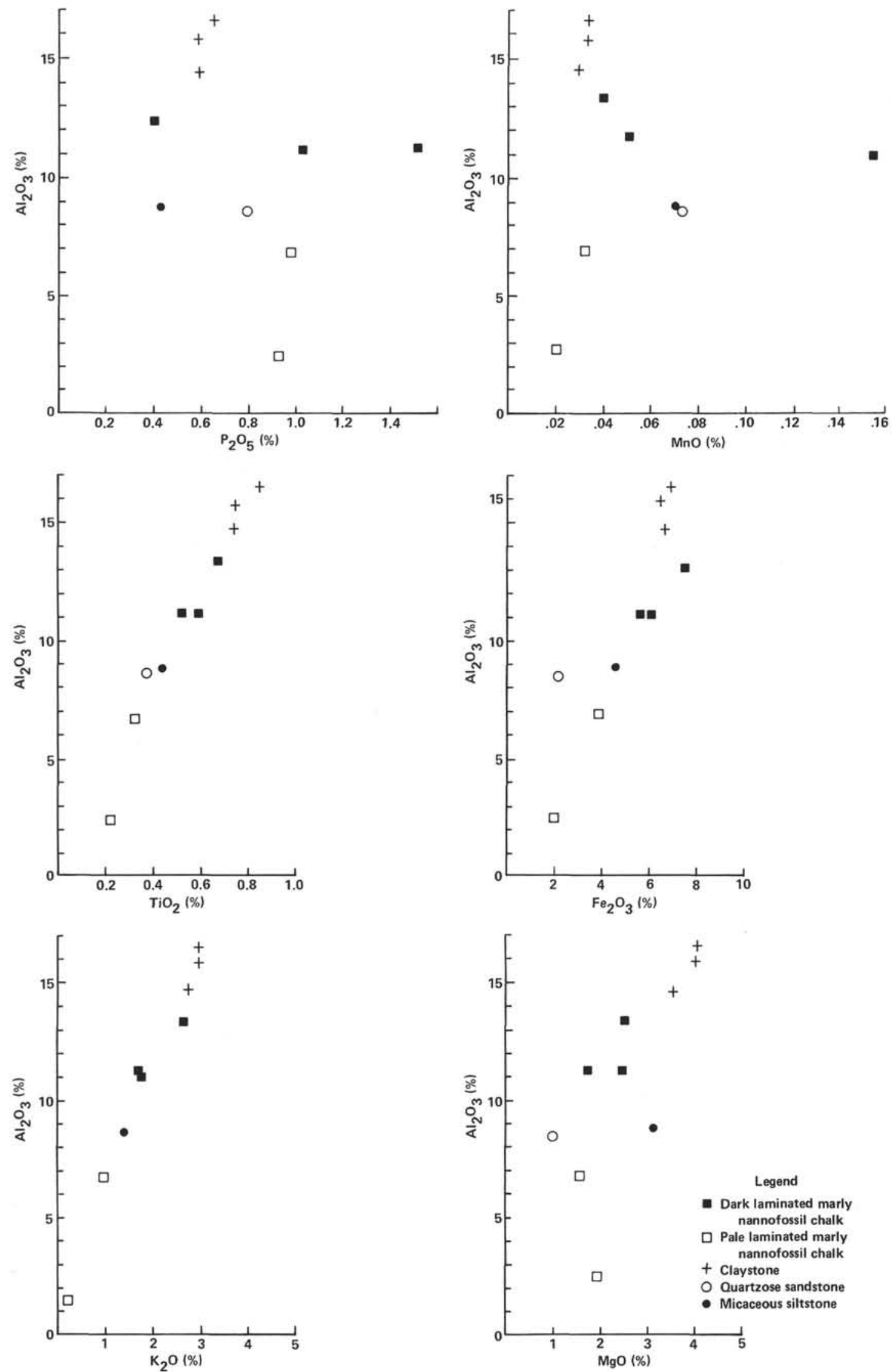

Figure 19. Graphs of relationships of major elements in Blake-Bahama Formation nannoplankton chalks and claystones. 
Table 5. $\delta \mathrm{C}^{13}$ and $\delta \mathrm{O}^{18}$ isotopic values for Hole $534 \mathrm{~A}$ samples from the Blake-Bahama Formation.

\begin{tabular}{lccc}
\hline $\begin{array}{c}\text { Sample } \\
\text { (core-section, } \\
\text { interval in cm) }\end{array}$ & $\begin{array}{c}\text { Sub-bottom } \\
\text { depth (m) }\end{array}$ & $\mathrm{C}^{13}$ & $\mathrm{O}^{18}$ \\
\hline $48-3,50-52$ & $959.0-963.5$ & +0.686 & -3.102 \\
$50-4,7-9$ & $972.5-981.5$ & +1.650 & -2.509 \\
$52-4,6-9$ & $990.5-999.5$ & +1.497 & -2.718 \\
$56-2,88-90$ & $1026.5-1035.5$ & +2.010 & -3.482 \\
$58-5,38-40$ & $1044.5-1053.5$ & +1.411 & -2.689 \\
$61-1,8-12$ & $1071.5-1080.5$ & +1.192 & -4.696 \\
$64-1,90-93$ & $1098.5-1107.5$ & +1.817 & -3.994 \\
$68-5,55-58$ & $1130.0-1139.0$ & +1.948 & -2.602 \\
$69-3,25-27$ & $1139.0-1148.0$ & +2.031 & -3.217 \\
$72-6,57-66$ & $1166.0-1175.0$ & +2.553 & -2.127 \\
$74-6,73-76$ & $1184.0-1193.0$ & +2.479 & -4.617 \\
$76-6,33-37$ & $1202.0-1211.0$ & +1.512 & -4.011 \\
$80-3,78-81$ & $1233.5-1242.5$ & +0.999 & -3.195 \\
$83-5,115-117$ & $1260.5-1268.0$ & +1.541 & -1.891 \\
$84-2,99-101$ & $1268.0-1277.0$ & +1.414 & -2.258 \\
$87-5,62-65$ & $1295.0-104.0$ & +1.364 & -2.039 \\
$88-1,68-71$ & $1304.0-1313.0$ & +1.500 & -2.809 \\
$90-2,29-33$ & $1322.0-1331.0$ & +1.623 & -3.171 \\
$91-4,45-48$ & $1331.0-1340.0$ & +1.547 & -2.484 \\
& & +1.634 & -3.185 \\
$92-4,28-39$ & $1340.0-1349.0$ & +1.634 & -1.915 \\
$93-3,8-11$ & $1349.0-1353.5$ & +1.627 & -3.096 \\
$95-3,83-93$ & $1362.5-1371.5$ & +2.275 & -2.135 \\
$107-1,41-45$ & $1464.0-1468.5$ & +3.048 & -2.691 \\
\hline & & & \\
\hline & & &
\end{tabular}

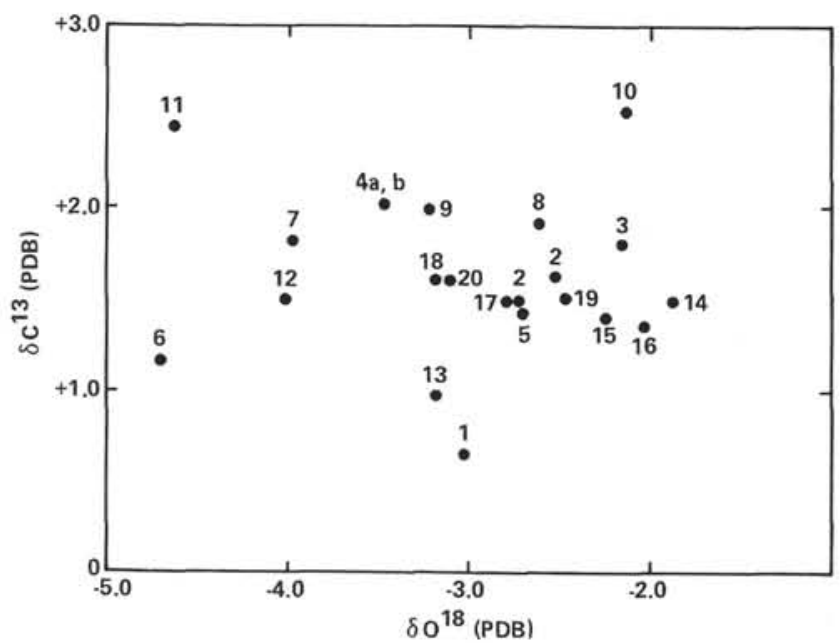

Figure 20. Crossplot of $\delta \mathrm{C}^{13}$ versus $\delta \mathrm{O}^{18}$. (The values are marine and show no progressive changes in any direction, indicating no significant changes occurred in depositional setting or diagenetic alteration.)

spond to the subunits identified at Site 534 (Table 6). Each subunit at Site 534 is thicker than its counterpart at Site 391, except the b subunits, which are comparable. The d subunits, composed of burrowed nannofossil limestone rich in radiolarians, are virtually identical, with abundant stylolites and scattered replacement chert nodules and aptychi. The pink and red upper Berriasian interval in Core 85 does not appear at Site 391, possibly due to poor recovery. In Site 534 the transition from nannofossil limestone of Subunit 5d to very well laminated nannofossil chalk and limestone of Subunit

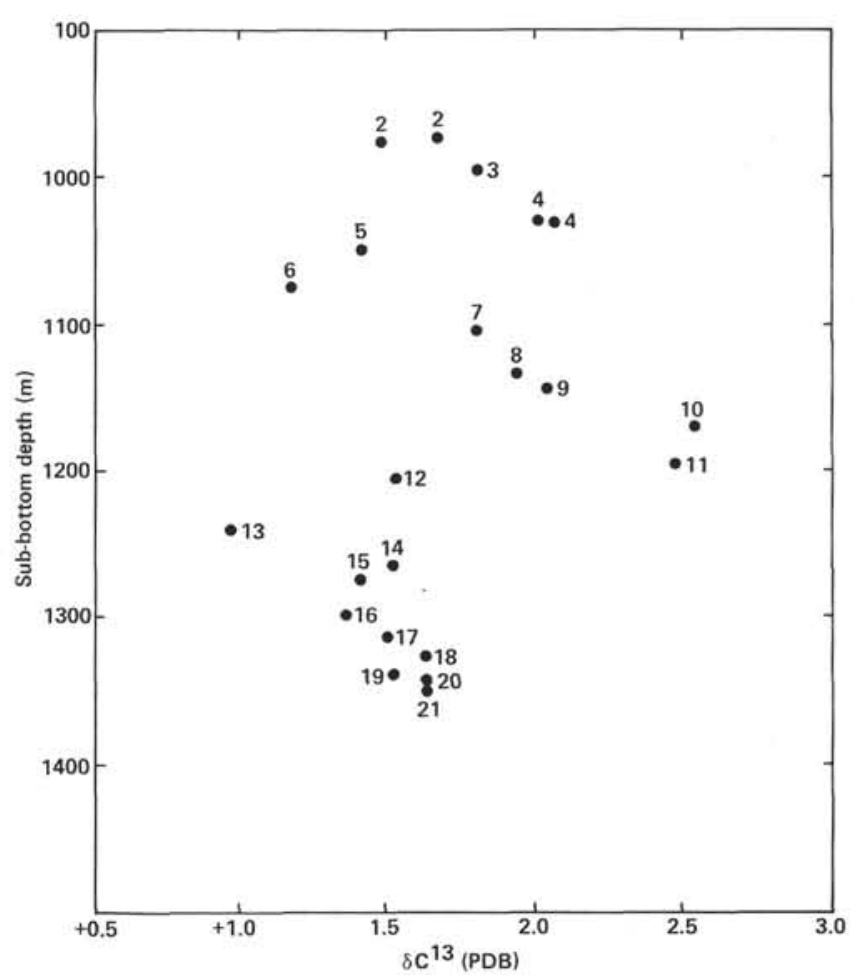

Figure 21. Plot of $\delta \mathrm{C}^{13}$ versus depth below the seafloor. (Again no trends are observed, indicating no carbon migration and a fairly closed diagenetic system.)

$5 \mathrm{c}$ occurs abruptly in the lower Berriasian. In contrast, the core photographs show a much more gentle transition at Site 391 between Cores 38 and 32 .

At Site 391 the $c$ subunit, characterized by bioturbated nannofossil limestone and finely laminated chalks, is comparable with the c subunit at Site 534, but the Site 391 subunit contains considerably more finely laminated nannofossil marls and turbiditic claystones. Differences in age shown in Table 6 could be artifacts of paleontological dating.

The b subunits, which are equivalent in thickness at both sites (Table 6), are made up of closely comparable, very finely laminated, marly nannofossil chalks intercalated with nannofossil-limestones and thin graded calcareous claystones. The ages assigned vary from early to late Valanginian for Site 534 and late Berriasian to lower Valanginian for Site 391.

The a subdivision of Site 534 is substantially thicker than its counterpart at Site 391 (Table 6). The base of both subunits is taken to be where turbidites are reduced to scattered, fine-grained partings, in both cases near the early/late Valanginian boundary. At Site 534 the top of the Blake-Bahama Formation is located where the background sediments first became noncalcareous, signifying deposition below the calcite compensation depth. By contrast, at Site 391 the transitional interval of highly calcareous millimeter-laminated Aptian claystones is placed in the overlying Subunit 3c, part of the Hatteras Formation of Jansa et al. (1979). In particular, the interval with redeposited clastics dated as late Valanginian to Barremian is significantly thicker at Site 534 than at 


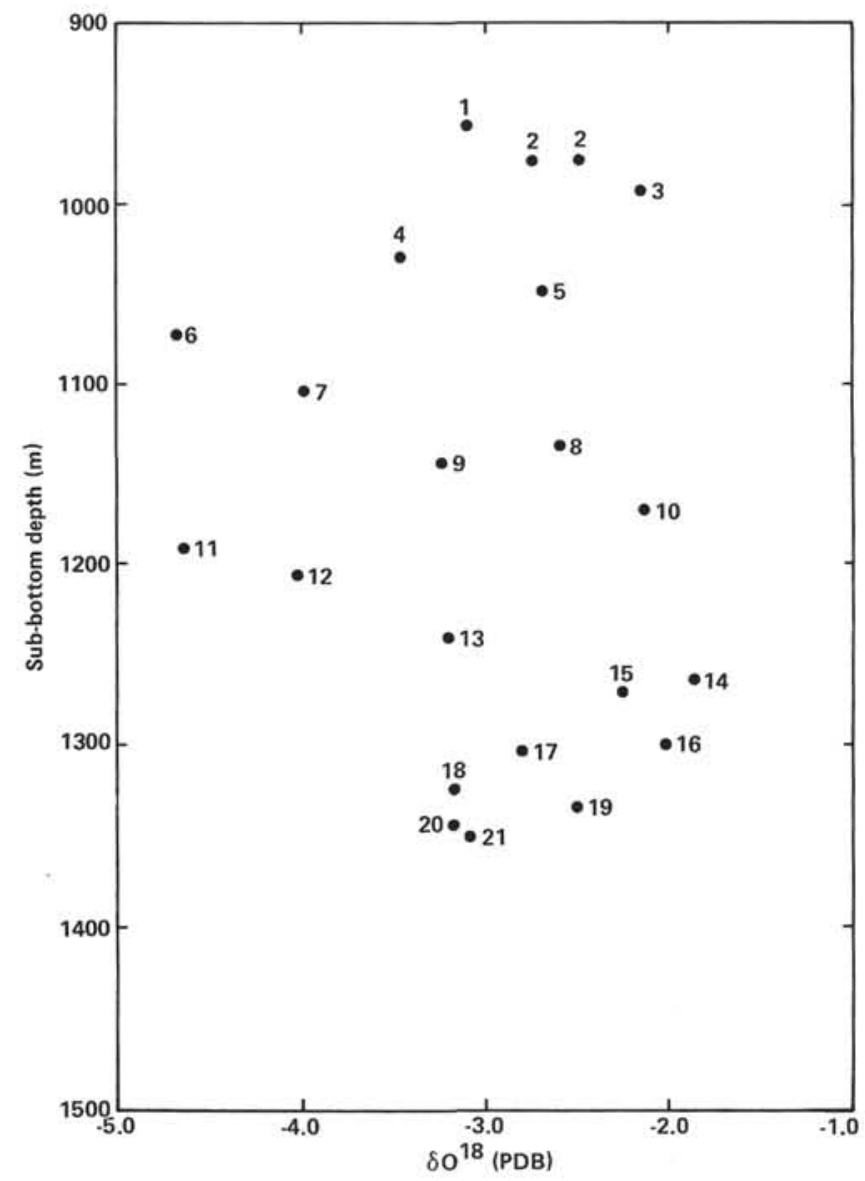

Figure 22. Plot of $\delta \mathrm{O}^{18}$ versus depth below the seafloor. (No trends are evident, reflecting the uniform water temperatures throughout deposition and a closed diagenetic system.)

Site 391. Individual calciturbidites are thicker and more numerous than their Site 391 counterparts, whereas the background depositions remain similar.

In summary, bearing in mind the uncertainties of age data: (1) the interval of very finely rhythmically bedded marly nannofossil chalks is thicker and apparently of longer duration at Site 534 than Site 391 (mostly Valanginian), (2) quartzose calciturbidites are thicker and more numerous at Site 534. Presumably, Site 391 was farther from a point source of dispersal (canyon) or the clastics at Site 534 were derived from a separate, more active source area.

\section{Atlantic Lower Cretaceous Elsewhere}

Finely laminated calcilutites like those at Sites 534 and 391 were also cored in the lower Valanginian interval at Site 387 on the western Bermuda Rise (Fig. 1). There the upper Berriasian to lower Barremian consists of burrowed limestones, thinly laminated limestones, marly chalk, marly limestone, and calcareous claystone. The light gray burrowed limestone is more abundant at Site 387 than Site 534, where it dominates the lower Berriasian interval. Various darker carbonates at Site 387 contain siderite, as well as abundant dolomite, not seen at Site 534 .
At Site 105, on the Atlantic Lower Continental Rise hills (Fig. 1), the Tithonian-Berriasian interval consists of gray to white chalky limestone interbedded with finely and evenly laminated clayey zeolitic silty limestone. This configuration resembles closely Subunit $5 \mathrm{~d}$ at Site 534. In both cases bedding has been largely destroyed by burrowing.

At Site 101 at the south end of the Blake Plateau outer ridge (Fig. 1), several intervals of finely laminated nannofossil chalks are seen, like those at Site 534 (e.g., Hole 101, Core 10, Section 1-Hollister, Ewing et al., 1972). Lancelot et al. (1972) note that the dominant feature of this material is the regular almost cyclic alteration of: (1) white to pale gray limestone, with an occasional pale greenish hue (almost homogenous, with abundant burrows) and (2) dark greenish gray, finely laminated, soft clayey limestone. Laminations are about $1 \mathrm{~mm}$ thick and horizontal except in slumped layers. This succession resembles that at Site 534 but is without the quartzose calciturbidites in the upper Valanginian and Hauterivian.

Very similar parallel lamination is again characteristic of the Lower Cretaceous interval of the Cape Verde Rise at Site 370 (Lancelot, Seibold et al., 1978) and in the South Atlantic (Bolli, Ryan, et al., 1978). Regional similarities with the Tethyan Maiolica facies are reviewed by Bernoulli (1972), Bernoulli and Jenkyns (1974), and Robertson and Bernoulli (1981).

Drilling in the Florida Straits has recently revealed a Lower Cretaceous succession again similar to that at Site 534 (Buffler, Schlager et al., 1981). Pelagic Barremian to Aptian limestones and black marls were deposited at average rates of $5 \mathrm{~m} / \mathrm{m} . \mathrm{y}$. This unit represents the distal edge of a wedge-shaped unit that thins away from the foot of the Florida platform. Beneath, the well-bedded Hauterivian to Berriasian consists of pelagic limestone with interbeds of black marl, which was deposited at average rates of $14 \mathrm{~m} / \mathrm{m} . \mathrm{y}$., somewhat lower than the Blake-Bahama Formation rates at Site 534. In contrast to Site 534, terrigenous material is absent from the Cretaceous at Site 535 (Buffler, Schlager, et al., 1981). Other holes drilled on Leg 77 (at Sites 536, 537, 538) reveal shallow-water bioclastic carbonates either deposited as a talus apron at the base of a platform (Site 536) or an autochthonous limestone cap on top of a fault block (Sites 537, 538).

In contrast to the Florida Straits, Blake-Bahama seismic reflections cannot at present be correlated directly with the Blake Plateau. However, shallow-water carbonates drilled at Sites 390 and 392 (Leg 44) can be correlated paleontologically with the top of the Blake-Bahama Formation at both Sites 391 and 534 (Benson, Sheridan, et al., 1978; M. Moullade, personal communication, 1980).

\section{DEPOSITIONAL AND DIAGENETIC MECHANISMS}

\section{Pelagic Chalks and Limestones}

The background pelagic sediment throughout the Lower Cretaceous at Site 534 is nannoplankton radio- 
Table 6. Comparisons of thickness of subunits at Sites 534 and 391.

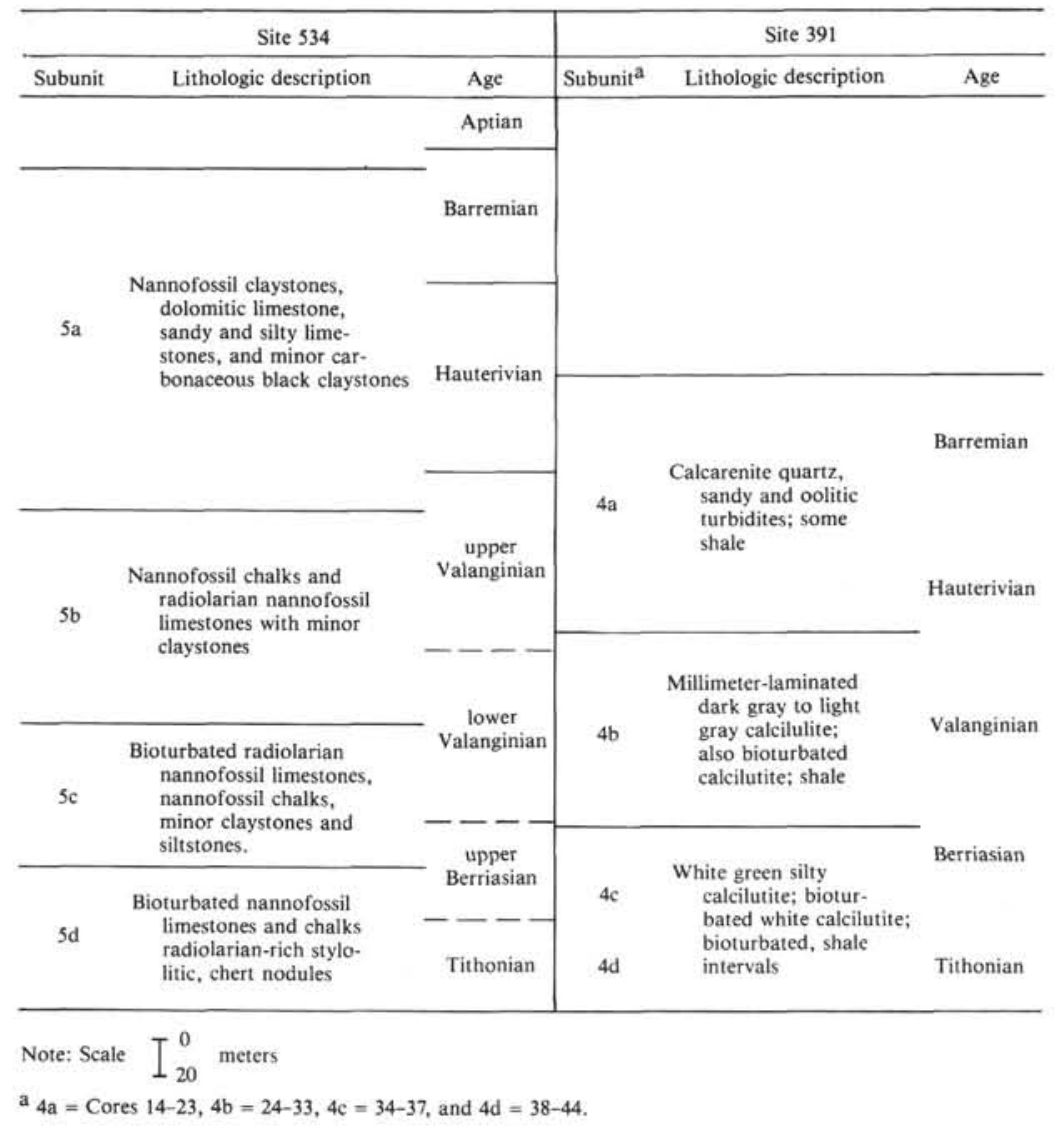

larian ooze. The paleontological age data indicate average accumulation rates of about $21 \mathrm{~m} / \mathrm{m}$.y., ignoring compaction. Calculated rates differ little from the bottom to the top of the formation, despite the much higher input of clastic material in the Hauterivian (Subunit 5a). In the modern equatorial Atlantic, sedimentation rates are in the range of 20 to $40 \mathrm{~m} / \mathrm{m}$.y. (Schott, 1935). At Site 534 rates of deposition decrease to about $10 \mathrm{~m} / \mathrm{m}$.y. in the overlying Hatteras Formation, reflecting the deposition below the calcite compensation depth.

Preservation of aptychi but not aragonite in the Berriasian at Site 534 shows that deposition was continuously above the calcite compensation depth, but at times below the aragonite compensation depth. M. Moullade (personal communication, 1980) notes the scanty abundance and rare preservation of the microfaunas in comparison with rich Tethyan contemporaneous assemblages. However, other Atlantic sites also appear to be depleted in planktonic foraminifers relative to the $\mathrm{Te}$ thys, which suggests that for some reason productivity of foraminifers was less in the Atlantic. Possibly, planktonic foraminifers preferred the near-margin environments represented in the Tethys, rather than the open oceanic setting drilled by DSDP. Alternatively, radiolarians may have been favored over foraminifers in a more fertile Atlantic. In the case of Site 534, deposition was almost certainly close to the calcite compensation depth, because backtracking gives paleo-water depths of circa 3300 to $3650 \mathrm{~m}$ (Sheridan, this volume).

\section{Claystones}

Virtually all the thin-bedded claystones show subtle grading and other sedimentary structures indicative of turbidite deposition. The turbiditic claystones occur independently of other lithologies, including the terrigenous quartzose clastics that are restricted to the higher levels of the formation. Both claystones and quartzose clastics, however, do reach a maximum together around the Valanginian/Hauterivian boundary. The claystones contain redeposited pelagic carbonate plus fine-grained terrigenous material. In contrast to the intercalated limestones and marly nannofossil chalks, nannofossils are extremely well preserved, showing little compaction or diagenetic alteration. Following the views of Chamley (e.g., 1979; this volume), the clays, which are dominated by smectites and mixed-layer clays, were probably ultimately derived from the continent where the climate fluctuated from arid to wet over short periods.

The clay was transported to the ocean, mixed with nannofossil ooze well above the calcite compensation depth, then transported by turbiditites to Site 534. Theoretical supply routes would be (1) the same submarine channels as the coarser-grained clastics took (see the discussion that follows), (2) the outer continental rise beneath the continental platform, which was bypassed by coarser clastics, or (3) platform areas already submerged by the Early Cretaceous. The separate identity of the claystones and coarser clastics rules out a common trans- 
port pathway. Drilling of the northern part of the Blake Escarpment, on the Blake Nose, shows that shallow-water carbonate deposition took place there until the late Early Cretaceous (certainly by the Barremian, when subsidence and pelagic carbonate deposition began). Although the history of the Blake Escarpment farther south is not known, subsidence as early as the late Berriasian when the turbiditic claystones appear at Site 534 seems unlikely. The present steep profile of the Blake Escarpment precludes the extensive areas of pelagic carbonate accumulation on either the upper or lower continental rise. On the other hand, Enos and Freeman (1979) note that shallow-water limestones of the Blake Nose show no signs of a barrier reef edge, suggesting the existence of a broader carbonate platform edge. In the Early Cretaceous the Blake Escarpment may have resembled the modern windward Bahama margin, where a very high percentage of muddy pelagic sediments accumulated both on the upper slope and in the basin, while sands and gravel dominated in the lower slope (Mullins and Neuman, 1979). As suggested by Paul and Dillon (1980), a very steep present profile of the Blake Escarpment may relate to Tertiary erosion by bottom currents. Redeposition from highs within the ocean is ruled out by the evidence that basement topography was covered beneath a smooth sediment cover by the Late Jurassic (Sheridan, Gradstein, et al., this volume). In summary, the turbidite claystones are thought to have been redeposited by turbidity currents off the upper continental rise onto the abyssal plain.

\section{Black Shales}

Many of the turbiditic claystones, particularly in the lower to upper Valanginian and near the Hauterivian/ Barremian boundary (Fig. 2), are relatively enriched in organic carbon (up to $3.9 \%$ ). Organic chemical analyses (this volume) and palynology (Habib, this volume) show that this organic carbon is mostly terrigenous in origin.

On a broad scale the central Atlantic Lower-midCretaceous black shales could be explained either by an "anoxic event," or by an expanded oxygen-minimum zone (Schlanger and Jenkyns, 1976; Fischer and Arthur, 1978). The anoxic "Black-Sea model" has been particularly applied to the South Atlantic in the Lower Cretaceous (Bolli, Ryan, et al., 1978) and to the Central Atlantic in the Upper Cretaceous (Fischer and Arthur, 1978). In any wide ocean the conventional view of "anoxic events" has some problems. A quiet stratified ocean is hard to reconcile with the apparently warm equable climate, because without circulation, heat transport is impeded and strong climatic gradients build up between the pole and equator. This in turn would tend to promote cold deep-water circulation.

In the case of the Central Atlantic Lower Cretaceous the evidence that much of the terrestrial organic material has been redeposited from quite shallow depths, probably on the upper continental rise, tends to reduce the need for a stratified ocean. Incidently, on Leg 76, the shipboard sedimentologists also noted that much of the black shales was also redeposited in the Cretaceous
Hatteras Formation, which implies that even there the role of "anoxic events" could have been exaggerated.

In the modern oceans, anoxic waters mostly form below areas of upwelling (e.g., western continental boundaries). Possible analogies to the Atlantic Lower Cretaceous are found today along the Ivory Coast and Ghana where the intermediate waters are oxygen-depleted (about $1.5 \mathrm{ml} / \mathrm{l}$ ) but not anoxic. The bottom water below $2000 \mathrm{~m}$ there contains abundant terrestrial organic matter reflecting a warm humid climate onshore (e.g., Demaison and Moore, 1980). An anoxic intermediate layer is well developed in the Bay of Bengal despite relatively low surface productivity (von Strackelberg, 1972). In the oxygen-minimum zone there, olive gray muds are deposited, which contrast with the light brown muds deposited in deeper oxidizing waters. Thus the model of an expanded oxygen-minimum zone in the Central Atlantic Lower Cretaceous is fully consistent with the evidence of redeposition and the abundance of radiolarians, which imply upwelling and relatively high surface productivity (see the discussion that follows). During the Early Cretaceous, major deltas carried vast volumes of terrigenous clastics and organic matter to the Atlantic margins (Jansa and Wade, 1975; Einsele and von Rad, 1979; Robertson and Stillman, 1979). Denser clastic material was concentrated on the shelf, then funnelled through canyons to the abyssal plain, while the lowerdensity plant material and clay floated out to sea, settled from suspension on the continental rise within the oxygen-minimum zone, and then was redeposited into more oxidizing abyssal bottom waters (see the following discussion).

\section{Redeposited Clastics}

The coarser-grained clastics were almost all deposited by turbidity currents and record the waxing and waning of sediment wedges during the Valanginian to the Barremian. In terms of depositional mechanisms, when the turbiditic clastics first appear in the Valanginian, the sedimentary structures comprise the more "distal" Bouma $\mathrm{T} \mathrm{c}, \mathrm{d}$, e intervals, but $\mathrm{T} \mathrm{a}, \mathrm{b}, \mathrm{c}, \mathrm{d}$ and various combinations thereof are present in the lower to upper Hauterivian (e.g., Core 58). These beds also show slumping and debris flow, which record unusually major redeposition events on the adjacent margin.

The terrigenous clastic material is found mostly in the upper Valanginian, Hauterivian, and Barremian, whereas the redeposited shallow-water clastics are mostly seen higher, in the upper Hauterivian and Barremian. The terrigenous clastic material was derived from both acid intrusive, granitic or granodioritic rocks (perthite, microcline) and metamorphic rocks (epidote, muscovite, zircon). Biotite, plagioclase, fresh biotite, and microcline are particularly abundant in some thin sections. The terrigenous clastic material was probably eroded from rivers in the southeastern United States, and then it bypassed the carbonate platform and upper continental rise through submarine channels. The fresh biotite precludes much sediment reworking in seawater before final deposition. The rare debris flows that reached the 
basins probably travelled through the same well-developed submarine channels.

In the Hauterivian the redeposited carbonate is mostly micritic, but above this in the Barremian shallow-waterderived material includes ooids, and corraline algae. The redeposited carbonates were presumably derived from somewhere on the Blake Plateau, away from the channels that transported the terrigenous clastic material. As mentioned above, the only part of the Mesozoic carbonate platform drilled on Leg 44 (Benson, Sheridan, et al., 1978) is the Blake Nose well to the northwest of Site 534 (Fig. 1). Drilling at Sites 390 and 392 revealed Lower Cretaceous shallow-water carbonates; these were present until the continental margin was submerged, with deposition of pelagic calcareous oozes, starting in Barremian. As pointed out by Enos and Freeman (1978), the source of both the carbonate and the quartzose material was the adjacent Blake Plateau area rather than the Bahamas to the southwest.

The input of both terrigenous and calcareous clastics relates to climate and sea level changes in the Early Cretaceous. The Early Cretaceous quartzose clastics reflect circum-Atlantic high terrigenous input related to growth of deltas during a period of humid warm equable climate (Einsele and von Rad, 1979). The delta outbuilding presumably outstripped the transgressive effects of sea level rise (e.g., Vail et al., 1977). Rising sea level may have stimulated carbonate productivity on the adjacent shelf as lime-secreting organisms tried to keep pace with sea level rise. Alternatively, at least on the Blake Nose, pelagic carbonates had already begun to be deposited by the Barremian. Possibly, loading with terrigenous clastics earlier in the Early Cretaceous inhibited organic carbonate construction so that platform growth failed to keep up with subsidence. Some areas may have remained as shallow horsts supplying shallow-water carbonate material throughout the Barremian, and possibly longer. Regional seismic coverage and drilling results show that during the Early Cretaceous, carbonate banks extended northwards from the Caribbean as far as the Canadian margin (Jansa and Wade, 1975; Smith et al., 1976; Perry et al., 1975).

\section{Dark-Light Couplets}

One of the most distinctive features of particularly the Valanginian and Hauterivian interval at Site 534 is the existence of light-dark marly nannofossil chalk couplets on an average scale of several tens of centimeters. The two types are smoothly intergradational. Darker couplets contain more organic carbon of terrestrial origin (Habib, this volume) and tend to be less burrowed, but otherwise compositions are very similar. Within the limitations of dating, couplets represent on the average $30-50,000 \mathrm{yr}$. The dark-light couplets occur independently of both the claystone turbidites and the ubiquitous fine lamination (see the discussion that follows), which is seen in both the darker and the lighter marly nannofossil chalks.

Dean et al. (1978) attributed cycles of similar organicrich and organic-poor pelagic carbonates with a period- icity of circa 50,000 yr. in the Cape Verde Basin to climatically induced pulses of organic material, which began in the Late Jurassic and continued until the Eocene. At Site 357 couplets of light gray limestone and dark olive marlstone are particularly well developed with a periodicity of circa $37,000 \mathrm{yr}$. in Cores 25 to 32 , dated as Barremian to Turonian. Jansa et al. (1978, see also Arthur and Natland, 1979) note that the cycles match the orbital periodicity, pointing to a link with fluctuating climate.

One other suggestion (McCave, 1979a) made to explain oxidized/reduced couplets is that bottom-water circulation was triggered at the 19,000 -yr. precession or the 41,000 obliquity-periodicity. Bottom-water renewal would favor rapid sediment oxidation. Consistent with this, McCave notes that the couplets at Site 387 (Leg 43) are asymmetrical, with a gradual increase in carbon content, then a sudden change to oxidized burrowed sediment. However, no such asymmetry is seen in the Site 534 couplets, which are smoothly intergradational. Also, sedimentary structures show no signs of repeated bottom-water replacement.

In summary, the preferred explanation of the darklight couplets at Site 534 is that climatic fluctuations on land, possibly related to cyclical variations in insolation, generated more prolific vegetation, thus varying the amount of terrestrial organic material that was supplied to the oceans through rivers. The fine low-density organic matter floated to sea, was transported by surface currents, then settled to form the darker, more organicrich, nannofossil couplets.

\section{Origin of Fine Lamination}

The ubiquitous fine lamination of the marly nannofossil chalks first appears in the Berriasian and persists until the Aptian. These laminations are unusual in their extreme regularity and persistence over long intervals. Other areas where comparable fine lamination has been drilled in the Central Atlantic are shown on a map of the configuration of this part of the Atlantic in the Early Cretaceous (Fig. 23). At Site 391, Freeman and Enos (1978) noted similar fine lamination in marly nannofossil chalks generally $1 \mathrm{~mm}$ thick. Close inspection in some cases revealed a compound nature, with up to 67 laminations per centimeter, which would be equivalent to 1 lamination per $6 \mathrm{yr}$., on the average. At Site 534 we were unable to resolve more than about 30 laminations per centimeter, equivalent to 1 lamination per approximately $15 \mathrm{yr}$. more.

In general, fine lamination in the deep ocean can result from (1) fine-grained distal turbidites, (2) current or nepheloid deposits (i.e., contourites), (3) variation in terrestrial input, (4) surface productivity fluctuations, or (5) diagenetic limestone-clay segregations.

As turbidites, the fine laminations could be interpreted only as repeated Bouma $\mathrm{T} d$ divisions. This possibility is ruled out because (1) there is no other background deposition ( $\mathrm{T} \mathrm{e}$ ); (2) laminae remain of constant thickness throughout the cores; (3) occurrence is independent of the turbiditic terrigenous clastics and claystones de- 


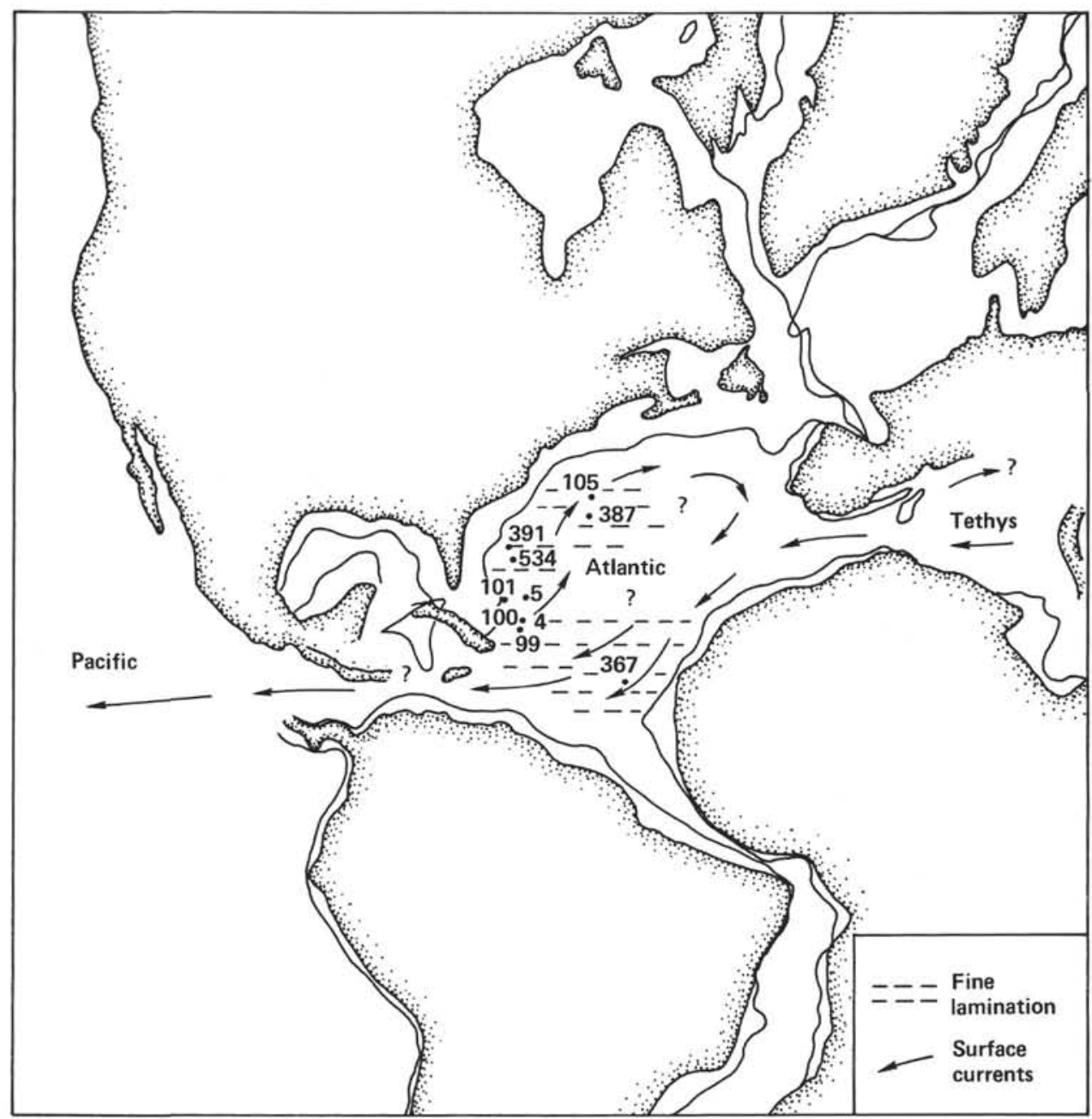

Figure 23. Reconstruction of the Central Atlantic in the Early Cretaceous, showing the approximate location of DSDP sites, inferred surface circulation, and the probable distribution of the regular millimeter lamination (reconstruction after Smith and Briden, 1977).

scribed earlier; and (4) no proximal-distal thickness variations are seen regionally, for example, in the BlakeBahama Basin relative to the Cape Verde Basin.

Formation of the fine lamination by current deposition is not supported either. At least some bottom-current activity is indeed evidenced, for example, by the preferential orientation of grains in thin section. However, the truncated tops of some of the silt- and sandsized turbidites probably resulted from subsequent turbidity current erosion, rather than more continuous bottom currents. In addition, first, the laminations are regular and laterally continuous within cores, without ripples, small-scale cross-bedding, scours, or other sedimentary structure normally associated with current deposits (cf., Stow, 1979). Second, unlike true contour currents, like the Holocene contourites of the Blake Outer Ridge (Heezen et al., 1966; Hollister and Heezen, 1972), the lamination is not restricted to the lower continental rise but occurs widely on the abyssal plain in both east and west Central Atlantic. Third, the fine lamination differs from the classic contourites cored, for example, at Site 533 on the Blake Outer Ridge (Sheridan,
Gradstein, et al., this volume). These are muddy nannofossil oozes with very few visible sedimentary structures. On the other hand, probable contourites cored in the Callovian interval at Site 534 do show the frequent ripples, truncations, and cutoffs normally associated with current deposits (Sheridan, Gradstein, et al., this volume). Fourth, seismic reflectors of the Blake-Bahama Basin are level, in contrast to the hummocky signature that seems to characterize contourites (Sheridan, Gradstein, et al., this volume). Deposition from fine-grained nepheloid drift is also not consistent with the lamination picked out by relatively coarse radiolarian tests and fine-grained silt visible in some thin sections.

Fluctuations in organic matter input could also be invoked to explain the light-dark nannofossil couplets on scales of several tens of centimeters. As noted above, fine lamination continues unaffected through these cycles. Thus either much shorter periods and highly regular fluctuations exist for which there is no evidence (minimum, ca. $7 \mathrm{yr}$.) or the lamination is unrelated to terrigenous input. Notably, when resolved with thinsections and scanning electron microscope, the lamina- 
tions consist of calcareous nannoplankton and radiolarians, often without visible fine-grained terrigenous material.

Cyclical fluctuations in surface plankton productivity could explain the regularity and widespread nature of the lamination throughout the Central Atlantic. Bottom currents would have been sufficient to orientate grains but not to significantly erode and redeposit material. An implication is that single laminae could be time planes extending over large areas of the ocean floor. The chief problem with this otherwise attractive model is the identification of the cause of surface productivity variation. Repeated algal "blooms" could produce a "varve-type" lamination. In the South Atlantic (Site 361, Cape Argentine Basin) Upper Cretaceous carbonaceous mudstones were deposited in tranquil bottom waters. Some intervals contain hundreds of millimeter-thick laminations, shown with the SEM to be composed of calcareous nannoplankton that show no signs of burrowing or current influence (reviewed by Arthur and Natland, 1979). The Blake-Bahama laminations are similar and in scale but show at least minor bottom-current activity.

Repeated algal "blooms" could conceivably have been caused by upwelling that gave rise to long-periodicity blooms (i.e., $10 \mathrm{yr}$.) in the equatorial ocean, which contrasts with the more seasonal productivity variations in more temperate waters in the modern oceans (Funnel, cited in McCave, 1979a).

As discussed by van Andel (1981; see also Arthur and Natland, 1979), during the Early Cretaceous the Atlantic may have been open to both the Tethys and the Pacific. Whether an unbroken connection existed through the Caribbean remains unclear, but the lack of major anoxicity as in the South Atlantic during the Late Cretaceous suggests open ocean connections. An open Pacific-Atlantic-Tethys connection would imply a strong narrow westward surface drift. Irregularities in the location and velocity of southwest-flowing return gyres could have produced surface nutrient patchiness stimulating pulses of productivity. In summary, surface productivity pulses seem the best way to explain the ubiquitous fine lamination, but the exact cause remains obscure.

\section{Role of Diagenesis}

Pyritization of radiolarians, particularly in the dark gray to black carbonaceous intervals, took place early in diagenesis, prior to significant compaction. The radiolarian shells are spherical in the purer burrowed nannofossil chalks but flattened in the more clay-rich and organic-rich intervals. Clay and organic matter are known to inhibit calcite cementation. As shown in Fig. 24, during times of lower clay or organic matter input, bottom water remained sufficiently oxidizing to promote rich infauna that underwent turbation and largely destroyed the original fine lamination. These purer chalks, in which spherical radiolarians are still preserved, lithified early, whereas the less clay- and organic-rich oozes underwent strong compaction prior to final lithification. In the vicinity of the purer limestones some $\mathrm{CaCO}_{3}$ has migrated to form cement in the purer limestones. Stylolites only formed in the purer limestones, particularly those at the base of the succession in the Berriasian. The

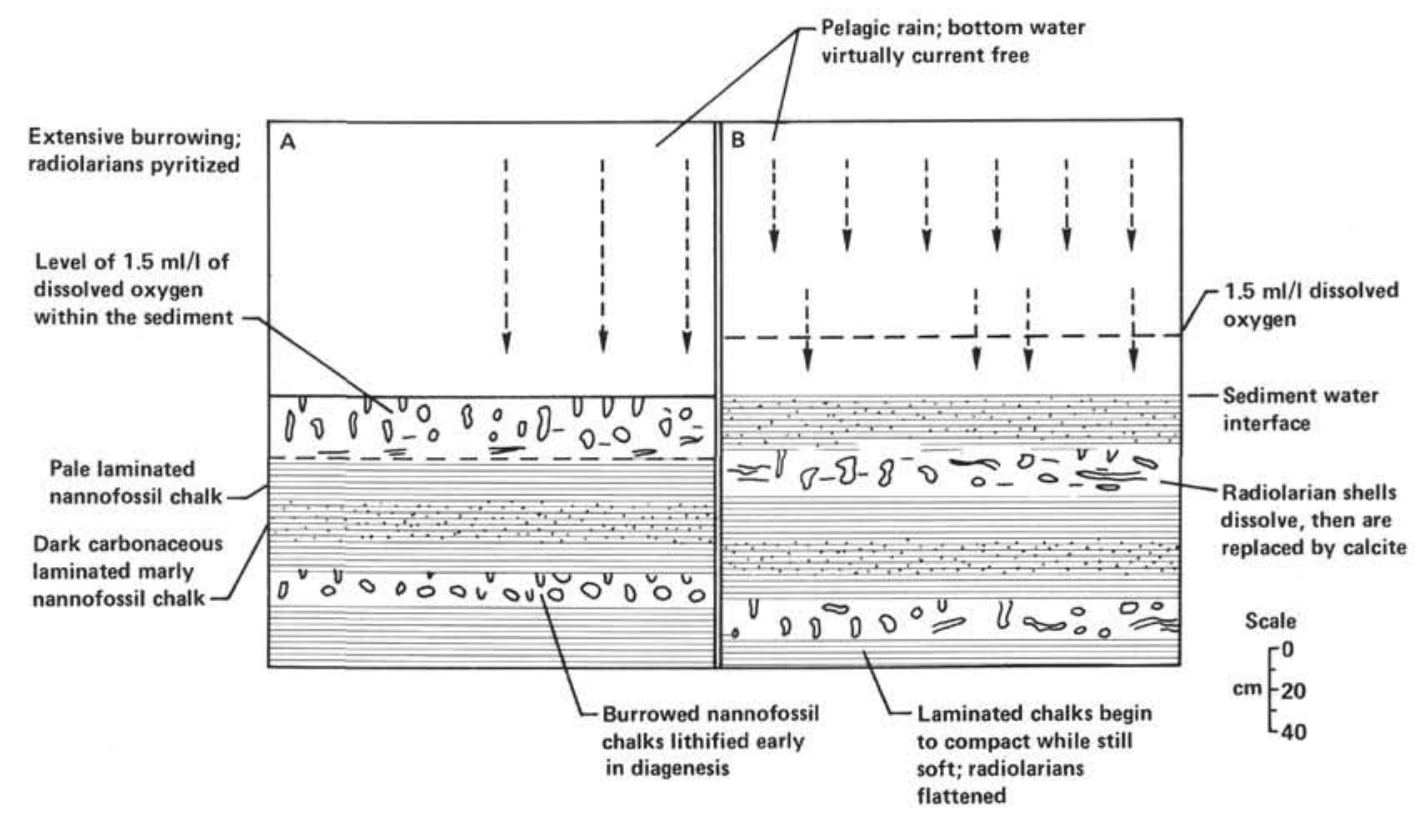

Figure 24. Diagenesis of Blake-Bahama sediments. A. Time of low terrigenous input, representing a dry period on land. (The bottom waters remained oxygenated, allowing a rich infauna to flourish. The purer limestones lithified early in diagenesis, forming the limestone rhythms). B. During a wetter period on land more terrigenous organic matter reached the abyssal plain. (Interstitial waters became depleted in oxygen, and burrowing organisms were killed off. Oxygen depletion may have extended a short distance into the water column, but generally the bottom water was oxidizing and circulating at least sluggishly. The more muddy and organic-rich intervals lithified only later in diagenesis after significant compaction.) 
radiolarian shells, which are infilled and replaced by calcite, must have dissolved and released silica near the sediment/water interface, thus explaining the scarcity of chert nodules. During times of greater organic input, interstitial waters became reducing right up to (and possibly slightly above) the sediment/water interface. These layers are devoid of infauna and preserve the fine lamination perfectly. Thus the principal role of diagenesis was to produce the rhythmical pale, burrowed dark, unburrowed couplets and intensify the ubiquitous fine lamination.

\section{Summary of Paleoenvironments}

As shown in Fig 25, during the Early Cretaceous a markedly expanded oxygen-minimum zone intersected with the upper continental rise, which was the source area for clay turbidites (but there is no need to invoke deep-water oxygen depletion with anoxia to abyssal depths) (cf., Arthur and Natland, 1979). The abundance of radiolarians and deposition rates are roughly comparable with the modern Atlantic Ocean (taking compaction into account). Waters were not continuously stable nor stratified. As discussed above, cyclical upwelling pulses lead to repeated "blooms", and can explain the ubiquitous fine lamination. Bottom waters appear to have circulated sluggishly, because grains are orientated, but currents were not strong enough to rework the fine primary lamination. Bottom waters were generally oxidizing. During times of higher terrigenous organic matter input, interstitial waters were depleted in dissolved oxygen and these conditions may have periodically extended a short distance up into the overlying water column. During the Early Cretaceous, depths of deposition ranged from 3300 to $3650 \mathrm{~m}$, below the aragonite compensation depth and near to and above the calcite compensation depth. Conditions conducive to formation of the Blake-Bahama Formation persisted over much of the Central Atlantic on both sides of the spreading axis for a period of $30 \mathrm{~m} . \mathrm{y}$.

\section{CONCLUSIONS}

1. Throughout the Berriasian to Aptian, nannofossil radiolarian oozes accumulated at water depths of 3300 to $3650 \mathrm{~m}$ (backtracking), close to and above the calcite compensation depth.

2. During the Hauterivian and Barremian, principally, major influxes of turbiditic terrigenous and carbonate clastics were derived from the Blake Plateau. These clastics bypassed the continental rise and were deposited onto the abyssal plain by turbidites and minor debris flows.

3. Claystone turbidites that are not related to the other turbiditic clastics were redeposited probably from the upper continental rise, which was bypassed by the terrigenous turbidites.

4. Black shales were first deposited on the continental rise within the oxygen-minimum zone, then redeposited as fine-grained turbidites onto the abyssal plain.

5. Surface waters were relatively fertile, stimulating relatively high radiolarian productivity. Repeated upwelling pulses may have produced "blooms" and thus formation of ubiquitous fine lamination. Bottom waters circulated sluggishly as shown by grain-orientation, but bottom-current erosion and reworking is minimal.

6. Climatic changes on land led to fluctuating of input of terrigenous organic matter on a time scale up to circa 50,000 yr. During periods of high organic input, bottom waters were depleted in dissolved oxygen, and this depletion excluded burrowers. During drier times of lower organic input, an infauna flourished in the purer nannofossil carbonates.

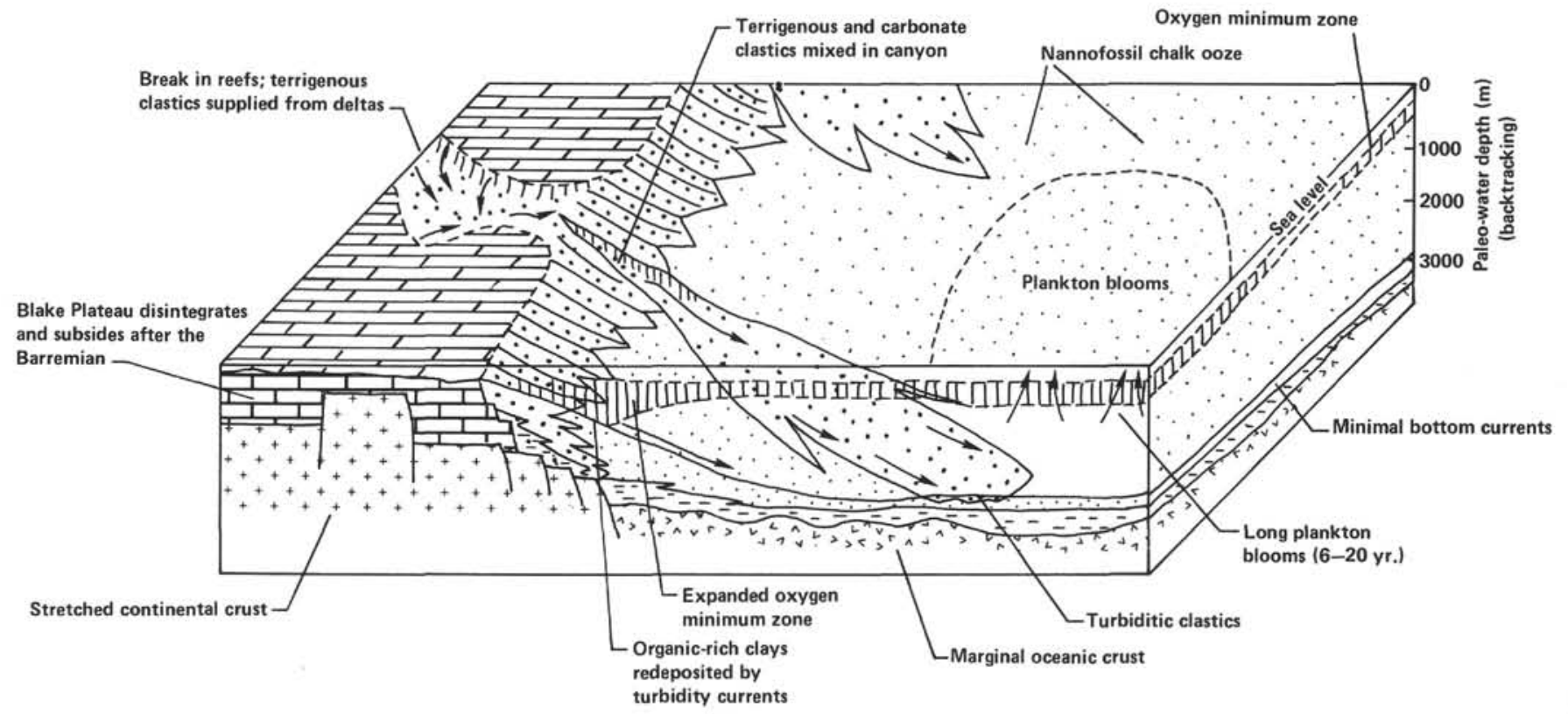

Figure 25. Block diagram to illustrate depositional processes in the western Central Atlantic during the Hauterivian to the Barremian. 
7. Purer nannofossil carbonates were cemented much earlier in diagenesis than the clay-rich or organic-rich intervals. Biogenic silica was released to seawater early in diagenesis so that chert is minimal. With subsequent compaction, the primary fine lamination was accentuated in the marly nannofossil chalks.

8. Blake-Bahama depositional conditions persisted over much of the Central Atlantic over 30 m.y. Site 354 reflects the delicate interplay of productivity, margin input, crustal subsidence, and diagenesis.

\section{ACKNOWLEDGMENTS}

For helpful discussion on the Glomar Challenger we would like to thank D. Habib, F. Gradstein, M. Moullade, P. Roth, and R. Sheridan. A. H. F. Robertson thanks Mr. G. Angell, Mrs. D. James, and Mr. J. Godall for assistance with X-ray analysis and SEM. D. Bliefnick thanks M. Overland for assistance with SEM photomicrographs, R. Burrus for isotopic analyses, and Gulf Research and Development Co. for microscope, SEM, isotope, and drafting facilities. We are also grateful for shipboard technical assistance. Helpful comments on a preliminary draft of the manuscript were received from $\mathrm{H}$. C. Jenkyns, L. Jansa, and J. Ogg. The manuscript was typed by Mrs. H. A. Hooker.

\section{REFERENCES}

Arthur, M. A., and Natland, J. H., 1979. Carbonaceous sediments in the North and South Atlantic: the role of salinity in stable stratification of Earth Cretaceous basins. In Talwani, M., Hay, W., and Ryan, W. B. F., (Eds.), Deep Drilling Results in the Atlantic Ocean: Continental Margins and Paleoenvironment. Am. Geophys. Union, Maurice Ewing Series 3, pp. 375-401.

Arthur, M. A., and Schlanger, S. O., 1979. Cretaceous "oceanic anoxic events" as casual factors in development of reef-reservoired giant oil fields. Am. Assoc. Pet. Geol. Bull., 63:870-885.

Bathurst, R. G. C., 1971. Carbonate Sediments and Diagenesis. Dev. Sedimentol., 12.

Benson, W. E., Sheridan, R. E., et al., 1978. Init. Repts. DSDP, 44: Washington (U.S. Govt. Printing Office).

Bernoulli, D., 1972. North Atlantic and Mediterranean Mesozoic facies: a comparison. In Hollister, C. D., Ewing, J. I., et al., Init. Repts. DSDP, 11: Washington (U.S. Govt. Printing Office), 801-871.

Bernoulli, D., and Jenkyns, H. C., 1974. Alpine, Mediterranean, and Central Atlantic Mesozoic facies in relation to the early evolution of the Tethys. In Dott, R. H., Jr., and Shaver, R. H. (Eds.), Modern and Ancient Geosynclinal Sedimentation. Soc. Econ. Paleotol. Mineral. Spec. Publ., 19:129-160.

Bolli, H. M., Ryan, W. B. F., et al., 1978. Init. Repts. DSDP, 40: Washington (U.S. Govt. Printing Office),

Buffler, R. T., Schlager, W., et al., 1981. Glomar Challenger operations, Leg 77. Joides J., 7(2):5-19.

Chamley, H., 1979. North Atlantic clay sedimentation and paleoenvironment since the Late Jurassic. In Talwani, M., Hay, W., and Ryan, W. B. F. (Eds)., Deep Drilling Results in the Atlantic Ocean: Continental Margins and Paleoenvironment. Am. Geophys. Union, Maurice Ewing Series, 3:324-361.

Dean, W. E., Gardner, J. V., Jansa, L. F., and Cepek, P., 1978. Cyclic sedimentation along the continental margin of Northwest Africa, Leg 41, Deep Sea Drilling Project. In Lancelot, Y., Seibold, E., et al., Init. Repts. DSDP, 41: Washington (U.S. Govt. Printing Office), 965-990.

Demaison, G. J., and Moore, G. T., 1980. Anoxic environments and oil source bed genesis. Am. Assoc. Pet. Geol. Bull., 64:1179-1209.

Einsele, G., and von Rad, U., 1979. Facies and paleoenvironment of Early Cretaceous (late Hauterivian) sediments in DSDP Site 397 and in the Aaiun Basin. In von Rad, U., Ryan, W. B. F., et al., Init. Repts. DSDP, 47, Pt. 1: Washington (U.S. Government Printing Office), 559-578.

Enos, P., and Freeman, T., 1978. Shallow-water limestones from the Blake Nose, Sites 390 and 392. In Benson, W. E., Sheridan, R. E., et al., Init. Repts. DSDP, 44: Washington (U.S. Govt. Printing Office), 413-462.
Ewing, J. I., and Hollister, C. D., 1972. Regional aspects of deep sea drilling in the western North Atlantic. In Hollister, C. D., Ewing, J. I., et al., Init. Repts. DSDP, 11: Washington (U.S. Govt. Printing Office), 951-995.

Fischer, A. C., and Arthur, M., 1978. Secular variation in the pelagic realm. In Cook, H. E., and Enos, P. (Eds.), Deep-water Carbonate Environments. Soc. Econ. Paleontol. Mineral. Spec. Publ., 25: 19-50.

Freeman, T., and Enos, P., 1978. Petrology of Upper Jurassic-Lower Cretaceous limestones, Site 391. In Benson, W. E., Sheridan, R. E., et al., Init. Repts. DSDP, 44: Washington (U.S. Govt. Printing Office), 463-475.

Heezen, B. C., Hollister, C. D., and Ruddiman, W. F., 1966. Shaping of the continental rise by deep geostrophic contour currents. Science, 152:502-508.

Hollister, C. D., Ewing, J. I., et al., 1972. Init. Repts. DSDP, 11: Washington (U.S. Govt. Printing Office).

Hollister, C. D., and Heezen, B. C., 1972. Geologic effects of ocean bottom currents: western North Atlantic. In Gordon, A. L. (Ed.), Studies in Physical Oceanography, (Vol. 2): New York (Gordon and Breach), 37-66.

Hudson, J. D., 1977. Stable isotopes and limestone lithification. $J$. Geol. Soc. London, 133:737-660.

Jansa, L. F., Enos, P., Tucholke, B. E., Gradstein, F. M., and Sheridan, R. E., 1979. Mesozoic-Cenozoic sedimentary formations of the North American Basin, Western North Atlantic. In Talwani, M., Hay, W., and Ryan, W. B. F. (Eds.), Deep Drilling Results in the Atlantic Ocean: Continental Margins and Paleoenvironment. Am. Geophys. Union, Maurice Ewing Series, 3:1-58.

Jansa, L. F., Gardner, J. V., and Dean, W. E., 1978. Mesozoic sequences of the Central North Atlantic. In Lancelot, Y., Seibold, E., et al., Init. Repts. DSDP, 41: Washington (U.S. Govt. Printing Office), 991-1031.

Jansa, L. F., and Wade, J. A., 1975. Geology of the continental margin off Nova Scotia and Newfoundland. Offshore Geology of Eastern Canada: Can. Geol. Surv. Paper 74-30, pp. 51-105.

Lancelot, Y., Hathaway, J. C., and Hollister, C. D., 1972. Lithology of sediments from the western North Atlantic, Leg 11, Deep Sea Drilling Project. In Hollister, C. D., Ewing, J. I., et al., Init. Repts. DSDP, 11: Washington (U.S. Govt. Printing Office), 901-950.

Lancelot, Y., Seibold, E., et al., 1978. Init. Repts. DSDP, 41: Washington (U.S. Govt. Printing Office).

McCave, I. N., 1979a. Depositional features of organic-carbon-rich black and green mudstones at DSDP Sites 386 and 387, Western North Atlantic. In Tucholke, B. E., Vogt, P. R., et al., Init. Repts. DSDP, 43: Washington (U.S. Govt. Printing Office), 411-416. 1979b. Diagnosis of turbidites at Sites 386 and 387 by particle-counter size analysis of the silt $(2-40 \mu \mathrm{m})$ fraction. In Tucholke, B. E., Vogt, P. R., et al., Init. Repts. DSDP, 43: Washington (U.S. Govt. Printing Office), 395-406.

Mullins, H. T., and Neumann, A. C., 1979. Deep carbonate margin structure and sedimentation in the Northern Bahamas. Soc. Econ. Mineral. Petrol, , 27:165-192.

Murdmaa, I. O., Gordeev, V. V., Bazilevskaya, E. S., and Emelyanov, E. M., 1978. Inorganic geochemistry of the Leg 44 sediments. In Benson, W. E., Sheridan, R. E., et al., Init. Repts. DSDP, 44: Washington (U.S. Govt. Printing Office), 463-476.

Norrish, K., and Hutton, J. T., 1969. An accurate X-ray spectrographic method for the analysis of a wide range of geological samples. Geochim. Cosmochim. Acta, 33:431-454.

Paull, C. K., and Dillon, W. P., 1980. Erosional origin of the Blake Escarpment: an alternative hypothesis. Geology, 8:538-542, and Discussion. Geology, 9:339-340, 1981.

Perry, W. J., Minard, J. P., Weed, E. G. A., Robins, E. I., and Rhodenhamel, E. C., 1975. Stratigraphy of the Atlantic continental margin of the United States north of Cape Hatteras-a brief survey. Am. Assoc. Pet. Geol. Bull., 59:1529-1548.

Robertson, A. H. F., and Bernoulli, D., 1981. Stratigraphy, facies, and significance of late Mesozoic to Early Tertiary deep water sedimentary rocks of Fuerteventura (Canary Islands) and Maio (Cape Verde). In von Rad, U. (Ed.), Geology of the Northwest African Continental Margin: Berlin, Heidelberg (Springer Verlag).

Robertson, A. H. F., and Stillman, C. J., 1979. Late Mesozoic sedimentary rocks of Fuerteventura, Canary Islands. J. Geol. Soc. London, 136:47-60. 
Schlanger, S. O., and Jenkyns, H. C., 1976. Cretaceous oceanic anoxic events: causes and consequences. Geol. Mijnbouw, 55:179-184.

Schott, W., 1935. Die foraminiferen in dem aquatorialen Teil des Atlantischen Ozeans. Deut. Atl. Exped. Meteor., 1925-1927 (3): 43-134.

Smith, A. G., and Briden, J. C., 1977. Mesozoic and Cenozoic World Maps: Cambridge (Cambridge University Press).

Smith, M. A., Amato, R. V., Furbush, M. A., Pert, D. M., Nelson, M. E., Hendrix, J. S., Tamm, L. C., Wood, G., Jr., and Shaw, D. R., 1976. Geological and operational summary, COST No. B-2 well, Baltimore Canyon Trough area, Mid-Atlantic OCS. U.S. Geol. Surv. Open File Rep. 76-744.

Strackelberg, U. V., 1972. Faziesverteilung in sedimenten des indischpakistanischen kontinentalrandes (Arabisches Meer). "Meteor" Forschungsergeb. Reihe $C$, 9:1-173.
Stow, D. A. V., 1979. Distinguishing between fine-grained turbidites and contourites on the Nova Scotian deep water margin. Sedimentology, 26:371-387.

Tucholke, B. E., Vogt, P. R., et al., 1979. Init. Repts. DSDP, 43: Washington (U.S. Govt. Printing Office).

Vail, P. R., Mitchum, R. M., Jr., and Thompson, S., III, 1977. Global cycles of relative changes in sea level. Am. Assoc. Pet. Geol. Mem., 26:83-97.

van Andel, Tj., 1981. Science at Sea, Tales of an Old Ocean: San Francisco (W. H. Freeman and Co.).

Date of Initial Receipt: June 17, 1982 